\title{
植物珪酸体，その特性と応用
}

\author{
近藤 鍊 $\Xi^{1)} \cdot$ 佐 瀬 隆 2

\section{Opal Phytoliths, their Nature and Application}

\author{
Renzo Kondo' ${ }^{1)}$ and Takashi SASE ${ }^{2)}$
}

\section{1.はじめに}

人間の主要栽培植物の多くはイネ科草本の仲間であ る.これらの葉身, 葉鞘, 根, 花序部などに宝石のオパ ールと光学的および理化学的性質の同一な, 微小な鉱物 が多数含有されている (MEtcalfe, 1960 ; PARRY \& Smithson, 1964, 1966 ; Blackman \& Parry, 1968 ; Pease \& Anderson, 1969 ; Bonnet, 1972). これらの 鉱物は, 植物起源のオパールといら意味で, Plant opal, Opal phytolith, Grass opal などの名称が土境学者によ ってつけられている (Bearvers \& Stephen, 1958; SMITHSON, 1958 ; BARKER, 1959a， b). 一方, 植物学者 は，古くから植物体の 表皮細胞に 珪素が沈積すること を認め，その細胞を珪化細胞と呼んだ（GROB，1896； Netolizky, 1929 ; Prat, 1936).

Plant opal（以下，植物珪酸体，あるいは珪酸体と略 記）の存在に最初に注目した一人に, 微化石研究の先駆 者である EHRENBERG がいる (BARKER, 1960a). 彼は， 空気塵, 雨水, 泥炭, 珃藻土などから形態の異なる多数 の植物珪酸体を分離, 記載し, ある種のものが特定の植 物に由来することを明らかにした（EHRENBERG，1847， 1854) .

その後, 若干の空白期間があるものの, 植物組織中の 珪酸体の形態, 分布, 数量が多種多様で, しか子特定の 植物に固有であることが主として植物学者によって認識 され (GROB, 1896 ; 大木, 1927-30; 早田, 1929 ; 佐竹, 1929-30 ; 加藤, 1932-33 ; Prat, 1936, Metcalfe, 1956，1960)，また，ロシアの土壤学者によって物質循 環の観点から土壤中の植物珪酸体についての研究が進め られてきた（RUPREAHT，1866；TYRIN, 1937 ; Usov,
1943).乙かし，環境復元法として植物珪酸体が注目され， その研究が飛躍的に進展したのは 1950 年代に SMITHSON (1956a，b，1958) の報告が公表されてからである.わ が国に拈ける植物珪酸体研究の先駆者である管野・有村 (1958a，b）抢よび加藤（1958）によって報告がなされ たのるこのころである.

植物珪酸体研究の初期のころに，前記の EHRENBERG (1838) によりトウヒの化石も発見されている. 花粉を 用いた環境復元法（花粉分析）は，前世紀の後半から北 欧諸国を中心に活発に行われ，その研究業績は膨大であ る（中村, 1967 ; 塚田, 1974)。一方，植物珠酸体は，一部 の研究者を除き汪とんど注目されず，花粉研究に大きく 遅れをとった，その最大の理由としては，同一植物でも 部位の違いによって生産される珠酸体の量および種類が 多様で，乙かも，植物間で類似の珪酸体が多数含有され ているために，植物珪酸体の特徴を十分把握できず，形 態の記載および分類に時間を要したことがあげられる.

屯た，植物珪酸体は，珪酸集積の多い植物以外に形成さ れず，古環境の復元法としては総合性に欠けると見なさ れたことも大いに関係していると思われる.

総合性に優れる花粉分析にもいくつかの弱点がある. まず，花粉はかなり遠方まで飛散するため広域的な植生 を復元するには適するが，局所的環境の復元にはあまり 有効とはいえない。ま, 地表に落下後, 比較的早く分 解消失するクスノキ科（中村，1967; TsukADA，1967) などの樹木,ならびそ花粉の形態が類似するイネ科植物 (中村，1967）の同定にはあまり適さない，さらに, 花粉 は還元状態下の泥炭地就よび海底などに落下した場合に は半永久的にその場所に保存されるが，火山灰地のよう な通気性の良い土壌, あるいは堆積物では花粉外壁の主

1) 带広畜産大学環境土裹学研究室 Laboratory of Environmental Soil Science, Obihiro University of Agriculture and Veterinary Medicine.

2) 盛岡第四高等学校 Morioka Fourth High School. 
成分であるスポロポレニンは酸化分解され残存しにくい (中村, 1967).

一方, 植物珪酸体は, 風塺, 糞として遠方まで運ばれ るものもあるが (SmItHSON, 1958 ; BARKER, 1959b, 1960d ; Folger et al., 1967)，飛散の程度も低く，概し て移動性に乏しい.そのため局所的な植生の復元には花 粉より優れた面がある。また，有機物（泥炭，腐植）に 乏しく，花粉化石がさほど含有していない堆積物和よび 土壤を対象とした場合，花粉分析に匹摘する古環境復元 法として大いに期待されている（ROVNER，1971）. そし て，なによりも，植物珪酸体は花粉で不十分なイネ科植 物の同定にその力を発揮することである（KURMANN， 1982).このように, 植物珪酸体分析は新しい可能性を 秘めた古環境復元のための解析法であるといえよら。

現段階では，イネ科植物を中心に，カヤッリグサ科, シダ類，ッユクサ科，ラン科などの草本類，ヤシ科を含 も樹木類について研究がおし進められているにすぎず， また，それらの植物でも全ての部位について検索されて いるわけではない。

しかしながら，これまで明らかにされた範团内です， 植物の各グループには特徴的な形態の珪酸体がそれぞれ 確認されており，植物珪酸体分析による古環境復元はこ れからますます発展することが期待されている (LUTWick, 1969 ; Rovner, 1971, 1975 ; Geis \& Jones, 1973 ; 加藤, 1977 ; WiLding et al., 1977 ; 塚田, 1980 ; Pearsall, 1982).

筆者らは，これまで植物珪酸体について数回にわたり 紹介(近藤, 1974, 1975，1977，1983a，b，1984a；佐瀬， 1980c）する機会を得たが，十分意をつくしたとはいい がたい.

そこで，本稿ではすでに紹介した内容を含め，植物珪 酸体の基礎的な側面と植物珪酸体の応用例を中心に論じ たい。

\section{2. 植物体における珪素の分布および役割}

大部分の植物はあらゆる部位に珪素を多少とも沈積さ せるが，とくに珪素集積の高い植物種や部位がある.

珪素集積の高い植物は, 系統樹の中でコッ植物, シダ 植物のヒカゲノカズラ類, トクサ類およびその一部の科, イネ科, カヤッリダサ科の一部に局存している（高橋, 1976a, b, 1981，高橋核か, 1981). また，植物体内で珪素 が最も集積する部位は葉部であり，イネ科植物では表皮 細胞, 樹木類では維管細胞と表皮細胞に掞いて珪素の集 積が著しい(PARRY \& SMITHSON, 1966 ; BonNET, 1972;
GEIs， 1973 ; 近藤，1975，1983a). これは，葉部でとく に蒸散作用が活発に行われ,『蒸発皿効果』として珪素 が沈積するためであると考えられている(BABA，1956； 吉田，1965). このことは，成熟した植物，あるいは生育 期間の長い植物が若い植物に比べて概して珪素含量が多 く (PARry \& Smithson, 1964 ; Wilding \& Drees, 1968 ; Johnston et al., 1967 ; SAngster, 1970), た熱 帯および业熱带地域の樹木が温带地域の樹木に比べると 珪素含量が高い傾向にあるという事実 (Amos，1952) とよく符合している。

一般に単子葉被子植物は双子葉植物の 10 から 20 倍 の珪素を含有している (WILDING et al., 1977). とく に, イネ科植物では $20 \%$ 以上の珪素を含有している種 もあるが，普通乾物当たり 5〜15\%である（NORGREN, 1973 ; 高橋. 三宅, 1976a ; Wilding \& DREES, 1968). 他方, 多くの樹木類の珪素含量は $1 \%$ 以下（最大 9.4 \%, Амоs, 1952) であり，とくに針葉樹のそれは少な い.しかし, 若干の樹木, 例えばモクレン科, クワ科, ブナ科抽よびニレ科の一部はイネ科植物に匹敵するほど 高い珪素を含有することもある（WILDING \& DREES， 1971 ; GEIs, 1973 ; 近藤, 1975). 以上のように, 植物体 内での珪素含量は, 植物の種類, 部位および生育時期な どによって異なる，これを決定する要因としては，植物 の潜在的珪酸吸収能, 蒸散作用, 土壤条件（とくに，水 素イオン濃度，アルミニュウム・鉄の存在）などの相違 があげられる (JoNES \& HANDRECK, 1963, 1967).

植物に括ける珪素の栄養生理学的役割については, 一 部（ケイ藻，イネ）、を除いてあまり明らかにされていな いが，一般には植物体の骨格的役割を果たしたり，葉部 の调萎を整えたり，また病害虫に対して保護作用をした りするとされている (YoshidA et al., 1962).

\section{3. 植物珪酸体の定義, 特性}

植物珪酸体は, コケ植物門, 維管束植物門などの高等植 物の細胞組織に充填する非晶質含水珪酸 $\left(\mathrm{SiO}_{2}, n \mathrm{H}_{2} \mathrm{O}\right)$ と定義される. したがって，単細胞藻類など，下等植物 の細胞膜に由来する含水珪酸は植物珪酸体とは呼ばない (近藤, 1983a).

植物珪酸体に対して，放散虫および海綿動物の体の内 外に発達する非晶質含水珪酸があるが，これは動物珪酸 体(宇津川ほか, 1979) と呼ばれて和り，とくに，地層の示 準化石として地質学的に重要である.なお，植物珪酸体 と動物珪酸体は，貝殼，歯などと共に Biolith(Bio : life, lith : rock)の範儔に包含される（JONES \& HAY. 1975)。 
植物珪酸体の化学組成は, 珪酸（67～95\%）を主成分 とし，それ水分 $(3 \sim 12 \%)$, 有㙨炭素 $(<0.1 \sim 6 \%)$ および少量の無機元素 ( $\mathrm{Al}, \mathrm{Na}, \mathrm{Ca}, \mathrm{Fe}, \mathrm{K}, \mathrm{Ti}$ ) を含 んでいる (Kanno \& Arimura, 1958b; Jones \& Beavers, 1963 ; Jones \& Maline, 1963 ; Arimura \& KanNo, 1965b ; Wilding et al., 1977 ; Bartoli, 1985)。なお, 植物体, 土壤, 拈よび宝石のオパールの 間で化学組成に大きな違いは認められない（WILDING et al., 1977).

植物拄酸体は, 通常無色であるが, 褐色あるいは黒色 を呈するものもある (JonEs \& MILNE, 1963). 有色の 程度は，含有する有機炭素量に多少とも関係する (WILDING et al., 1977). 土壤中では酸化鉄の被覆で黄褐色 から褐色を带びるが，脱鉄処理により本来の無色となる (Kanno \& Arimura. 1958b; 有村 - 菅野, 1965a, b). 光学性は一般に等方体であるが，異方体を示するのも稀 にある(加藤, 1960 ; WiLding \& DREEs, 1976). また, 植物理酸体は，土壤中で長期間埋積すると玉䯣を経て二 次石英に変質することもある (BERVERS \& STEPHEN, 1958 ; Jones \& Beavers, 1963 ; Yarilova, 1952).

属折率は 1.41 1.48 ときわめて低く, 比重は 1.5 $2.3 \mathrm{~g} / \mathrm{cc}$ である (Jones \& Beavers, 1963 ; KanNo \& ARIMURA, 1958b ; Wilding et al., 1967). こ水らの值 は, 植物珠酸体の含水量に左右され，例えば水が約 4 $\%$ から. $28 \%$ に增加すると屈折率は 1.46 から 1.40 に減少する. 同様に, 比重も 2.3 加 1.8 に減少する (WILDING \& DREEs, 1976). 比重は含水量のほかにも, 珪酸体内部の空洞の有無, 有機物の混入率物よび微細 な非晶質珪酸球体の配列などの違いによって変化する (WILding et al., 1977).

粒径は, $2 \mu$ 以下から $200 \mu$ 以上にも拉よび, 植物種 によってかなり幅が認められる (JoNes \& HAY, 1975). イネ科植物拉よび樹木から分離した珪酸体は 50〜 70\% が $5 \mu$ 以下の粒径である (JONEs \& BeAvers, 1964b; Wilding \& Drees, 1971 ; Geis, 1973).

比表面積は，珪酸体の粒径および形態によって異なる が, $0.4 \sim 122 \mathrm{~m}^{2} / \mathrm{g}$ とかなり大きい(PeInEmann et al., 1970 ; Wilding \& Drees, 1976).

$\mathrm{X}$ 線回折は， $4 \AA$ と $10 \AA$ 付近に微弱な幅広い反射が みられ, “X線非晶質”であり(WILDING \& DREES, 1974, 1976)，人士のシリカゲルに極めて類似している (JoNES \& Segnit, 1971). 土壤および植物体に拈いて，一部，

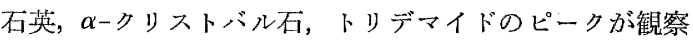
されるが，これは珪酸体分離時の処理温度および処理
時のアルカリ金属の存在によって非晶質珪酸が結晶性珪 酸へ転移した結果と考えられている (LANNING et al., 1958 ; Jones et al., 1964 ; Jones \& Milne, 1963 ; 有 村·营野，1965a).

な扮，樹木葉部起源珪酸体のX線回折によれば， $\alpha$-石 英およびクリストバル石は，自然の代謝作用によって葉 中で合成されたものであり，それらは分離調整時に生成 される人工物でないことが WILdING \& DReES (1974) によって指摘された、したがって，植物および土壤から 珪酸体を分離する際には，低温厕化 $\left(60^{\circ} \mathrm{C}\right)$ ，あるいは 湿式灰化のいずれか好ましい分離調整法を用いるべきで ある (Wilding et al., 1977).

土壤和よび植物体から分離した珪酸体の赤外線スペク トルは，シリカゲルおよび天然オパールのそれときわめ て類似している (YoshidA et al., 1962 ; JoNES \& BEAVERs， 1963 ; 有村 ·管野, 1965a ; WILDING et al., 1967). 研究者によってピーク位置にわずかの差が報告 されているが，吸收带は 460～470，785～800，1050～ $1110,1625 \sim 1650$, および $3425 \sim 3700 \mathrm{~cm}^{-1}$ の領域に それどれ分布している。

電子顕微鏡 (TEM) では，植物珪酸体は不規則な非 晶質珪酸の球体 $(0.5 \sim 1.0 \mu)$ によって充填された内部 構造が 観察される. 一般に宝石の才パールに比べてそ の球体は小さく，また，それらの配列も不規則である (Jones et al., 1966 ; Wilding \& Drees, 1974, 1976). 時折，植物体（とくに，樹木）で観察される不透明珪酸 体は, 光学顕微鏡では同定できないが，走查型電子顕微 鏡 (SEM) はそと同定にきわめて有効である(WILDING \& DreEs, 1971, 1973)

植物珪酸体の $50 \sim 600^{\circ} \mathrm{C}$ の反応範囲に和ける熱的特 性は, 珪酸体の給源植物，粒径，および分離調整時の処 理法などの違いに左右されるが，95〜 $120^{\circ} \mathrm{G}$ にないし 数個の水分に由来する吸熱ピーク， $350 \sim 500^{\circ} \mathrm{G}$ に有機 物の酸化に由来する幅広い発熱ピークがみられる（Jones \& Beavers, 1963 ; Jones \& Milne, 1963 ; Twiss et al., 1967).

土畩の各種環境下に和ける植物珪酸体の風化抵抗性に ついては不明な点が多いが，第三紀層和よび中生代の堆 積物から植物珪酸体が発見されていることから, 埋積環 境さえ良ければかなり安定といえよう (BARKER, 1960a； Jones, 1964 ; GILL, 1967).

Wilding \& Drees (1974), Wilding et al. (1979) 扣よび BARTOLI \& WILDING (1980) 怯, 植物珪酸体の 安定性を冷・温水あるいは薬品にたいする溶解性から評 
価した。すなわち，冷水特よび温水処理によって植物珪 酸体から 2 50 mgSi /l が溶解し，また， $0.1 \mathrm{~N} \mathrm{NaOH}$ 㵭沸処理によって樹木起源珠酸体の $35 \sim 80 \%$ が溶解し た。近藤ほか(未発表)によれば，1\%炭酸ナトリュウム， $0.6 \mathrm{~N}$ 塩酸打よび温水処理 $\left(60^{\circ} \mathrm{C}, 1\right.$ 時間) 飞上る植物 珪酸体の溶解性は，炭酸ナトりニウム $(25 \sim 176 \mathrm{mg} \mathrm{Si} /$ $>l)$ 温水 $(0.2 \sim 9.6 \mathrm{mg} \mathrm{Si} / l)>$ 塩酸 $(0.13 \sim 1.6 \mathrm{mg} \mathrm{Si} / l)$ の順であり, また植物種間で差が認められた。とくに, 針葉樹起源珄酸体はいずれの溶媒に対して抵抗性があっ た.このような植物玨酸体の溶解性の違いは, 珪酸体の 比表面積, アルミニュウム含量, 和水度, 年路, 招よび 珪酸体を包告植物組織の分解率など, 多くの要因が複雑 に関与した結果と考兄られている (BARTOLI \& SELMI, 1977 : Bartoli \& Wilding, 1980).

\section{4. 植物珪酸体の分離・定量法}

\section{1) 植物体}

植物から珄酸体を分離する方法は乾式法と湿式法の二 通りがある (図-1 参照).

乾式法（Lanning et al., 1958； Lanning，1961) は, 植物試料を磁性ルッボに取り，マッフル笹で灰化・冷却 後, 秤量する最も簡単な方法である。ただし，マッフル 炉に入れる前に試料は水洗いと稀塩酸温浸したるのを用 いる. 乾式法は試料の種類，加熱温度・時間なぞで灰化 の良し悪しが決まる。また，加熱汇よって植物珠酸体は 石英 $\left(573^{\circ} \mathrm{C}\right), \alpha$-クリストバル石 $\left(700^{\circ} \mathrm{C}\right), \quad$ トリデマ イド $\left(900^{\circ} \mathrm{C}\right)$ 飞一部变質(BeAvers \& Stephen, 1958; PARFENOVA \& YARILOVA，1962) したり,珪酸体同志が 結合 (Jones \& BeAVERs, 1964a) したりするので, 光 学性や物理性を調べる場合注意を要する，500 700 ${ }^{\circ} \mathrm{C}$ の条件で 5 時間程度の灰化が一般的である(菅野·有村, 1958a, b ; Jones \& BeAVERS, 1964a : JoNes \& MALiNe, 1963 ; Rovner, 1971 ; Twiss et al., 1969) .

湿式法 (Smithonon, 1958 ; Sterling，1967) は，化学 薬品により有機物のみを分解する方法で，操作がやや複 雑である. 化学薬品として, 過酸化水素, クロム酸, 過 塩素酸, 硝酸, 硫酸などが用いられている。とくに，過 塩素酸, 硝酸, 硫酸の混液 $(4: 10: 1)$ あるいは過塩素 酸, 硝酸混液 $(1: 1)$ 飞よる分解法が広く採用されてい る(Twiss et al., 1969 ; RovNer, 1971 ; BONNET, 1972; 佐瀬 - 加藤, 1976a ; 加藤, 1977 ; 塚田, 1980 ; 近藤, 1981)。この方法は，分解中に刺激ガス沶よび爆発性の過 塩素酸ガスが発生するのでドラフトを使用すること，分

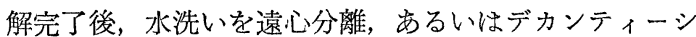

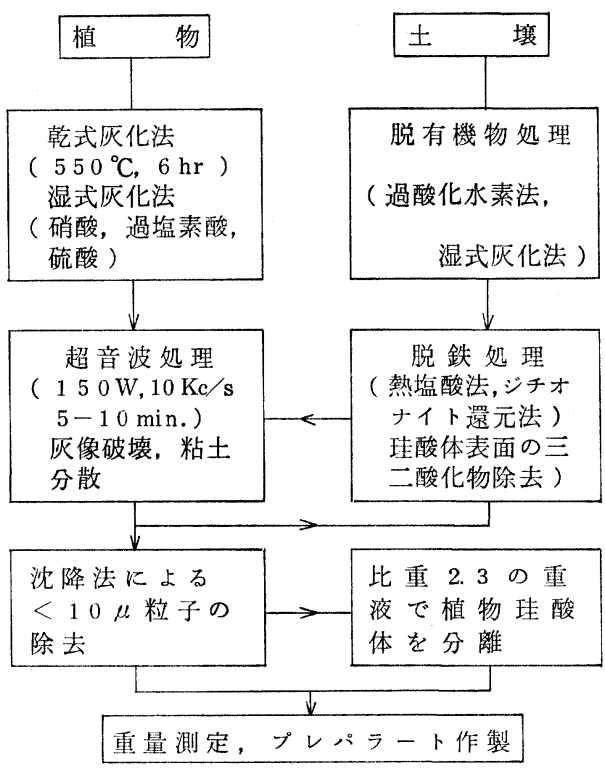

図 1 植物珪酸体の分離・定量法

ョンで十分拉こならことが大切である。

な特，乾式拈よび湿式の両方法で分離した試料は重量 を測定した後, 超音波処理によって灰像を完全に破壊し， $10 \mu$ 以下の粒径を沈降法によって除去する.ささらに, $10 \mu$ 以上の珪酸体は形態観察用として保存する.

上記の方法と平行して, 植物体を咸化した後, その扊 の組織像を調べる灰像法 (MoLICH，1920）を実施すべ きである。

灰像法（渡辺，1973-4）飞は，乾式法と湿式法があ る. 乾式法は，マッフル炬（またはバーナー）で灰化 する一般的な方法と，低温プラズマ曱化法 (Uмемото \& HozumI，1973) がある。前者は市販の灰化器（また はルッボ）で調整するが，灰像が収縮したり，もろくな りやすいので取扱に注意を要する．反面，後者は組織の 破壊がほとんどないが，装置が高価である．乾式灰化法 に対し，過酸化水素を用いる湿式灰化法は組織の变化が 少なく、なによりもイネ科植物葉身の表と裏側を分離し てそれぞれ観察出来るといら利点が出る，筆者らは，こ の方法で良い結果を得て和り，多くのイネ科植物葉身の 灰像標本を収集している。

\section{2) 土 壇}

土壤から植物珪酸体を分離する方法（図-1 参照）は， (1). 脱有機物処理 (過酸化水素法, 湿式灰化法), (2). 脱 鉄処理 (ジチオナイト還元法, 熱塩酸法)，(3). 超音波処 理 $(150 \mathrm{~W}, 10 \mathrm{Kc} / \mathrm{s}, 5 \sim 10$ 分) 拈よび(4). フルイ分け およびデカンティーション（沈降法により $10 \mu$ 以下の 
粒子を除去）の各操作をへた後, 重液（比重 2.30）で 行う（佐瀬 ·近藤, 1974 ; 加藤, 1977 ; 近藤, 1983a). この操作で最も重要なことは，土壤粒子を完全に分散さ せることで，このことがその後の珠酸体分離の良し悪し を決定する，したがって，有機物と鉄の除去は念入りに 行うことが肝要である。また，植物珪酸体はアルカリ性 で溶解し易いので, 可能な限り酸性条件で各処理を行ら 必要がある.な敊，植物珪酸体は水道水中に含まれる ことがあるので, デカンティーション時には可能な限り 純水を用いる.

重液は, ブロロホルム・アセトン（またはニトロベン ゼン) 混液, 四臭化ェタン・エチルアルコール混液, ツ ーレ液（ヨウ化カリ：ヨウ化水銀：水=7:6:2）など が用いられている (KanNo \& ARIMURA, 1958b; Jones \& Beavers, 1964b ; Oberholster, 1968 ; Rovner, 1971 ; JoNEs \& HAY, 1975).

重液分離は，重液と試料をほ济 $20: 1$ の割合で混合 し，遠心分離によって珪酸体を抽出する，その祭，浮上 物は肉眼で認められなくなるまで数回操り返す.浮上部 (珪酸体) はスポイト, 特殊な遠心管 (近藤, 1982a， c)， あるいは遠心管の下部を涷結させること（OBERHOLSTER，1968）などによって，ろ紙上に回収する．回収した 珪酸体は科量管に移し重量（w）省測定する。

なお，重液分離法の土壤試料の粒径は，研究目的に上 って異なるが，一般に $20 \sim 50 \mu, 10 \sim 100 \mu, 10 \sim 200 \mu$ が用いられている (Jones \& BEAvers, 1964a,b; 佐瀬. 近藤, 1974 ; Kondo, 1977).

あらかじめ土壤の容積重を測定しておくと，次式によ って土猿中の珪酸体含有量 $(\mathrm{Pw})$ が算出される（加藤， 1977).

$\mathrm{P} w=\mathrm{w} \cdot \mathrm{s} \cdot \mathrm{d} \cdot \delta \cdot 0.1\left(\mathrm{mg} / \mathrm{cm}^{2}\right)$

ただし， $\mathrm{s} は 10 〜 100 \mu$ 画分試料の重量 \%, d は土 層の厚さ， $\delta$ は土壤の仮比重である.上述の重液による 珪酸体の重量測定は, かなり煩雑であり, また浮上部に 珪酸以外の夾雑物が混入することも稀でない，そこで, 試料中の珪酸体個数（以下珪酸体密度と呼ぶ）を計測す る方法が提唱されている（藤原，1976a，b).

珪酸体密度は, 重量法, 容積法およびグラス・ビーズ による間接法によって測定されている. 重量法は, 数 $\mathrm{mg}$ の試料をプレパラートに展開した後, 珪酸体個数を 直接数える方法であるが，その精度に問題がある(藤原， 1976b). 容量法は, グリセリン中に試料を希釈し，マイ クロピペットで一定量を吸引し，プレパラートに展開す る方法である. 時間と労力を执しまなければ比較的良好
な方法といえよう・グラス・ビーズ法は，一定の大ささ のグラス・ビーズを同定率確定用として使い，とれらの 一定量を土壌と混合した後, グラス・ビーズと珪酸体の 粒数比から珪酸体密度を間接的に次式にしたがって求め る(藤原，1976b).

$$
S p=\frac{\mathrm{a} \times \mathrm{Gw}}{\mathrm{Sw}} \times \frac{\beta}{\alpha}
$$

ただし， Sw は試料の乾燥重量， $\mathrm{Gw}$ は添加グラス。 ビーズ重量, $\mathrm{a}$ はグラス・ビーズ $1 \mathrm{~g}$ 中の個数, $\alpha, \beta$ はそれぞれ数えたグラスビーズおよび植物珪酸体の個数 を表している.

この方法は，重量法和よび容量法に比べ時間的にも労 力的にも有利であるが, グラス・ビーズの比重, 粒径を 試料のそれに合わせること，それらの混合が十分なされ ることが前提である.

な敊，植物珪酸体 $1 \mathrm{~g}$ 中の個数 (n) がわかれば，次 式から試料の植物珪酸体含有量 ( $\mathrm{Pw}$ ) が算出できる.

$$
\mathrm{Pw}_{\mathrm{w}}=\frac{\mathrm{Sp}}{\mathrm{n}}(\mathrm{g})
$$

上述の方法のほかに，粒数パーセントを重量パーゼン 卜に換算する試みが提示されている（加藤， 1977 ; 加藤 ほか, 1980). すなわち, 細砂部 $(0.2 \sim 0.02 \mathrm{~mm})$ 中の 大型珪酸体の粒数パーセント $\left(\mathbf{n}^{\prime}\right)$ を求め, 次式によっ て理酸体含量 $\left(\mathrm{Pw}^{\prime}\right)$ を算出する.

$$
\mathrm{Pw}^{\prime}=\mathrm{n}^{2} \cdot \gamma \cdot \mathrm{fs} \cdot \delta \cdot 0.1\left(\mathrm{mg} / \mathrm{cm}^{2}\right)
$$

ただし，fs は細砂部の重量パーセント， $\gamma$ は $\mathrm{n}^{\prime}$ を細 砂当たり重量パーセントに換算する係数 $(0.55)$ である.

\section{3) 土器胎土}

土器胎土から植物珄酸体を分離する方法は，基本的に 土壤のそれと同でである.土器は焼成 $\left(600 \sim 800^{\circ} \mathrm{G}\right)$ 乙 ているので，土䁃と同じ方法では粒子を分散させること は極めて難しい，そこで，前処理として土器片を水中に 浸し，低真空で軟化した後，機践的に圧砕(藤原，1980) したり，鉄乳鉢で胎土中の細レキを注意深く粉 研した 後, 10 数回脱鉄処理を操り返す方法（上條， 1984） が 行われている. 最近, 近藤 (未発表) は, 湿式灰化（硝 酸, 過塩素酸, 硫酸混液) 叔よび超音波処理によって土器 片を軟化する方法を検討した：この方法は上記の二つの 方法に比べて，効率良く土粒子をほぐすことができる.

な拉，上記の各処理前に土器片表面の付着物をグライ ンダー，あるいは超音波洗浄によって除く必要がある.

\section{5. 植物珪酸体の形態およびその特徴}

植物珄酸体の形態は，それらの給源細胞組織の形にほ 


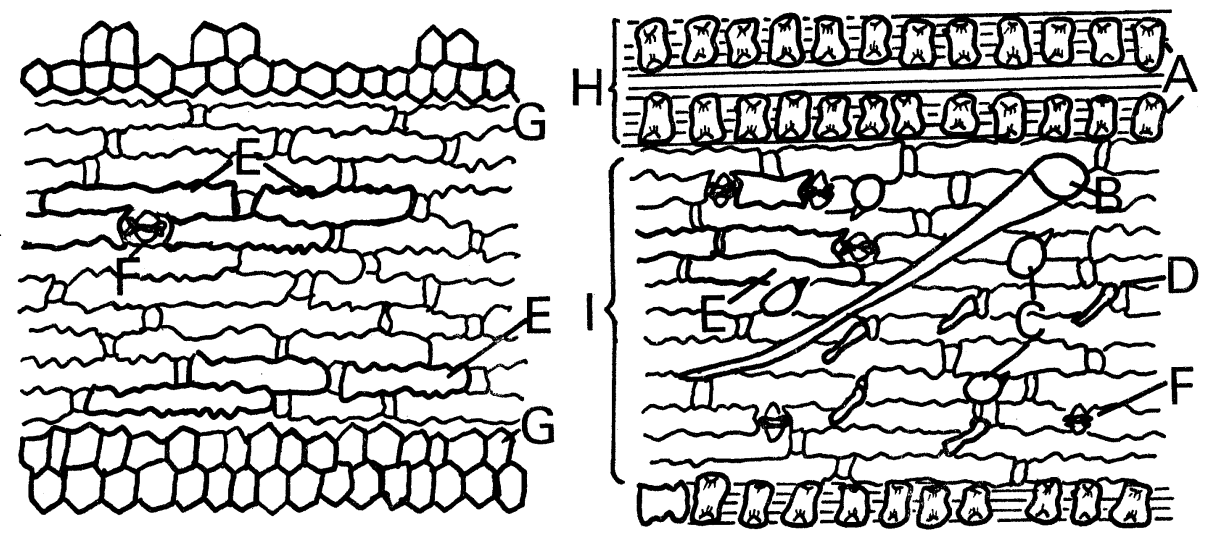

図 2 葉身表皮細胞中の植物珠酸体

$\mathrm{A}$ : 短細胞 (タケ型理酸体)， B : マクロヘアー， C : プリッヶルヘアー(ポイント型理酸 体), $\mathrm{D}$ : ミョロヘアー, $\mathrm{E}$ : 長細胞 (棒状型珪酸体), $\mathrm{F}:$ 気孔, $\mathrm{G}:$ 機動細胞（ファン 型珪酸体)，H：葉脈（実線の部分に葉脈が走っている），I：葉脈間. 左図は, エゾミヤコザサ (Sasa apoiensis) 葉身表側, 右図は裹側.

ぽ依存する (図-2 参照).

イネ科植物の皮表細胞は, 短細胞, 長細胞, 機動細胞 および特殊細胞（コルク，気孔，プリッケルヘアー、マ クロヘアー, ミクロヘアー, 乳頭突起) から構成される (Metcalfe, 1960).このうち, 短細胞は葉脈上の表皮細 胞に配列する小型の細胞で, 生育のごく初期に珪化す る. この内部に形成される珪酸体の形状は分類指標の一 つとされている (PRAT, 1936 ; Metcalfe, 1960). 寸な わち, キビ亜科では亜鈴形 (写真図版 $\mathrm{I} \cdot \mathrm{J} \sim \mathrm{R}$ ), イチ ゴッナギ亜科3)ではボート形, 帽子形, 星状形（写真図 版 I. S W ), タヶ亜科では長座鞍形 (写真図版 I.A 〜D), スズメガヤ亜科では短座鞍形（写真図版 I. E〜 G), ダンチク亜科では亜鈴形, あるいは短座鞍形（写真 図版 I.H）の各珪酸体が形成される.

短細胞以外の細胞も生育がす寸さにつれて漸次珪化 し, 細胞の形に支配された特有な珪酸体となるが, 短細 胞と異なり全ての細胞が珪化するわけではない。

長細胞には棒状形の 珪酸体（写真図版 II. I M) が でき, それらは平滑辺, 刺状辺などを有し, 側面が平滑 状, 刺状岁るいは鋸歯状の架起を示するのなどがある (Twiss et al., 1969).

機動細胞は，葉の展開運動を司り，水分蒸発防止機能 をもつといわれる葉脈間に配列する大型の 細胞である (Smithson, 1958 ; PARRY \& Smithson, 1964).この細 胞由来の珠酸体 (写真図版 II. A H) はそと断面の形状
が扇（または，食パン）状を呈し，属あるいは一部種レ ベルで微妙な差異が認められる（加藤，1960；佐瀬・近 藤, 1974 ; 藤原, $1976 \mathrm{~b}$; 藤原·佐々木, 1978 ; 近藤䚾 か, 1982 ; 河室, 1983c，1984). とくに，イネとその近 縁種では，属・種レベルで断面形状，側面突起，裏面紋 様の大きさなどに差があり，相㕕に区別される（藤原， 1976b，藤原・佐々木，1978)。一般にイチゴツナギ业科 では, 機動細胞の発達が悪く（佐瀬・近藤, 1974; 藤原, 1983)，それ由来の珪酸体はほと儿ど形成されない。プ リッケルヘアーは, 最も一般的な毛の細胞 (BARKER, 1960b) で, 石ぞく状，力ギ状形態の珪酸体（写真図版 II. N〜P) になる. マクロヘアーは，突起物の長い大 型の細胞で, ゴルフクラブ状の珪酸体 (写真図版II. T, U）になる。 ミクロへアーは，2 細胞性の小型細胞で， スワン型フラスコ状，パイプ状，L字状形態などの珪酸 体（写真図版II．Q～S ) になる.気孔は, 带鈴形あるい は上腕骨状形態の珪酸体 (写真図版 III. E) になる.

この他に，柶状細胞に由来するグローブ状あるいは和 ぐし状珪酸体（写真図版II. V〜X)，導管由来の棒ヤス リ状珪酸体 (写真図版 III. B , C)，コルク細胞由来の IIII. 状珪酸体（写真図版 III. G）などがある.

以上のよらな理酸体の特徴は, 主にわが国のイネ科植 物を対象したものであるが，諸外国の植物，例放ばブラ ジル，セシード地方のイネ科植物には，日本と異なる形 態の珪酸体が多数観察される (SENDULSKY \& LABOUR-

3）かっては，ウシノケグサ亜科として分類されていたが，今日ではイチゴッナギ亜科（Pooideae）として分類さ れるのが普通である。 
aiv, 1966 ; Campos \& Labouria, 1969 ; Figueiredo \& HANDRO, 1971). 今後, イネ科植物起源珪酸体の汎 世界的カタログ作りが必要である.

な书，葉部以外の各部位にも珪酸体は形成されるが， その研究はまだ不十分である (PEAsE \& ANDERSON, 1969 ; YeGK \& Gray, 1969 ; BlaGkMAN, 1971).

樹木葉部起源の珪酸体の多くは, 前述のイネ科植物起 源のそれと明膫に区別されるが，針葉樹起源珪酸体の一 部は，イネ科植物の機動細胞和よび長細胞起源珪酸体に 酷似している (BRydon et al., 1963 ; Wilding \& DRees, 1971 ; GeIs, 1973 ; KLEIN \& GEIS, 1978 ; 近藤・隅田, 1978). それらの珪酸体は, 柔細胞, 仮導管に由来する単 純な立方体あるいは不規則多面体形態を示し，それらの 側面および装面に一ソ状の円孔が観察される(KLEINE \& GEIs, 1978). BRYDON et al. (1963) は, トガサワラ属 の星状厚膜細胞に由来する珪酸体が他の樹木のとれと明 瞭に区別されることを報告した。

広葉樹起源珪酸体の形態は非常に豊富である。例え ば，モクレン科のタイサンボク,マンサク科のイスノキ， ブナ科などは維管束細胞由来のY字形, あるいは『へ』 の字形 (写真図版 N. I, J), ニレ科, クワ科, スイカズラ 科のタニウッギなどは表皮毛細胞由来の中空ソケット状 珪酸体（写真図版 N.M）を含有する (GEIs，1973； WILDING \& DrEEs, 1973 ; 近藤・ピアソン, 1981). 多く の広葉樹は，葉部表皮細胞に由来する四ないし五角形板 状, はめ絵パズル状珪酸体（写真図版N.A，B）を含儿で いる(GEIS, 1973 ; 近藤, 1975 ; Wilding \& DrEEs, 1971, WiLdING et al., 1977 ; 近藤・ピアソン, 1981). この他に, クスノキ科のヤマコウバシ拈よびクワ科住球状 (写真図 版 N.D ），タブノキはブレード状（写真図版 N.F, G), モクレン科拈よびスダジイは多面体状，紡錘状㘯るいは 塊状形態の珪酸体（写真図版 N.C，E）をそれぞれ含 有している(近藤，1975；Kondo，1977; 近藤・ピアソ ン，1981)。また，ヤシ科はその葉部表皮細胞にコンペ イ糖状，表面が顆粒状突起物で覆われた円錐状あるいは 円板状，とぐろ状形態の珪酸体が検出される（SEWDULKsy \& Labouriau, 1966 ; Kondo, 1977 ; 近藤・隅田, 1978).このらせ, コンベイ糖状珪酸体（写真図版 $N$, Q，T) は多くのヤシ科でごく普通に観察される（ToMilinson, 1961 ; CUTLER, 1978). 一方, 円錐状拉よび とぐろ状珪酸体は一部の属にの久観察され，前者（写真 図版 N.R，S）はクロッグ属（近藤，1984b)，後者は クジャクヤシ属(SENDULSKy \& LAUbouRIAU, 1966) に由
来する4).な和，コンペイ糖状珪酸体に類似するものは， オーストラリア叔よび㑲アフリカに自生するイグサ目の レスチオン科の茥に含有されている (GUTLER, 1978). 珪酸体は樹木葉部にのみに形成されるわけではなく, 材部特よび樹皮にも検出されている（DRUM，1968； 平田ほか, 1972 ; SGURFIELd et al., 1974 ; Righer, 1980 ; NANko \& CôTE, 1980 ; 南光 · CôTE, 1981).

木材組織中の珪酸体の存在は, 熱帯産材の主要な特徵 の一りとされて和り, 須藤活か (1967) は多数の南方材 について珠酸体の存在を検討した.

RICHER (1980) は, 約 750 種のクスノキ科拉よびそ の類縁科材中の珪酸体を走查型電子顕微鏡で検討し, そ の放射組織, 柔細胞, 絨維中には Smooth grains, Rough grains, おょび Aggregates の三タイプの珪酸体が 含まれていることを報告した. すなわら Smooth grains は, 極めて小さい $(5 \sim 12 \mu)$ 汪ぼ球状の粒子で, Litsea, Beilschmiedeak の一部の種㧊よび Endlicheria krukovii にの夕観察される，ごく稀れな珠酸体である. Rough grains は, $8 \mu$ から $35 \mu$ の不規則な外観を示 す球状粒子（成長したカリフラローの花序に類似）で, Mezilaurus などに典型的に観察される珪酸体（写真図版 N.N) である. Aggregates は, 不規則な外観および深 い亀裂の表面構造を持つ, 最も一般的な珪酸体（ミミズ の糞塊に類似）である.このタイプの珪酸体は, 粒径に かなり幅が見られ $(15 \sim 70 \mu)$, Beilschmiedia, Endinadra, Potameia の殆ど全ての種执よび Cryptocarya の一部 の種で検出される.

イネ科植物および樹木以外の研究は甚だ不十分といえ るが, 若下の植物で特徴的形態の珪酸体が検出されてい る (ROVNER, 1971 ; 近藤, 1982a). 例光ば, カヤッリグ サ科の葉部表皮細胞には先端が尖った中空ハット状（顆 粒状突起物が周辺に配列) の珪酸体 (写真図版 III. K M) が観察され (PARFENOVA \& YARILOVA, 1962; WITTY \& KNOX, 1964; Mehra \& Sharma, 1965 ; 近藤. 原田，1980)，それらはカヤツリグサ科に固有であるの で, Mehra \& Sharma (1965) によってカヤッリグサ 型と命名された。 また，それらの種子の表皮細胞中に も，ホック状（写真図版III. O，P）就よび表面が多孔質 の五ないし六角形板状珪酸体（写真図版III，Q）が検出 される (RAESIDE, 1970 ; 佐瀬, 未発表).

ラン科シンピジュウム属は, ヤシ科クロッグ属の珠酸 体に極めて似て括り，光学顕微鏡で注区別することは困 難であるが，とれらを走査型顕微鏡で観察すると，シン

4) 最近コモチクジャクヤシ葉部の表皮細胞学観察したところ，クロッグ属と同じ形態の珪酸体であることが 判明した。 
ピジュウム属の珪酸体（写真図版III. V, W) は小球体 で裏面が満たされた円盤状形態を示し，クロッグ属のそ れと明確に区別される（近藤，1984b)．この他に，ッユ クサ類, カンナ類, Criobalanea, Podoslemonace, Rapataceae 飞も特徴的形態の珪酸体が含有されている $\left(\mathrm{C}_{\mathrm{A}}\right.$ RLiquist, 1961 ; SENDULSKy \& LABOURIAU, 1966). シ ダ植物のトクサ類，ヒカゲノカズラ類就よびヒダ類の一 部は珪素含有量が高いが，大部分は同定不能の小破片で ある・トクサ類には背骨状のほかに，突起物をるつへル メット状珠酸体（写真図版 III. T, U) がみられる（近 藤・原田，1980)。ぬた，ワラビなぞ一部のシグ類には， その断面が三角形で, 表面に多数の小孔を有する棒状形 態の珠酸体（写真図版 III. S) が観察される（近藤・佐 藤, 1985 ; 佐瀬ほか, 1985). シダ類, アキカラマッ草 なぞの多くの草本類には, 広葉樹起源のはめ絵パズル状 珪酸体に類似した珪酸体 (写真図版III.R) がみられる. しかし, シダ類, 双子葉草本起源珃酸体の研究は今の之 ころ不備であり, 今後の研究課題とされる.

な特，植物体に就ける珪酸体の生成，発達過程打よび 機能などについての詳細な研究は, 各種の植物を対象と して植物学者（または, 作物学者) によって検討されて いる (PARry \& Smithson, 1958, 1964, 1966 ; HANDREK \& Jones, 1967 ; Blackman, 1968, 1969 ; BLACKman \& Parry, 1968 ; SAngster, 1970 ; Kaufman $e t$ al. 1971 ; ТАKEOKa et al., 1983 ; ТАKeOKa et al., 1983).

\section{6. 植物珪酸体の分類}

稙物珄酸体の分類は，イネ科植物，樹木類について一 部報告されているが，すべての植物を網羅した分類案は 未だ提示されていない。

イネ科植物の亜科掞よび若干の属は，その葉脈上の短 細胞に形成される珪酸体の形態に基づいて同定される。

Prat (1936) は, Panicoideaea を Eu-Panicoides (Melindeae, Paniceae, Tripsaceae, Andropogoneae の 4 属) と Chlorides (Chlorideae, Zoysieae の 2 属, Eragrostis, Sporobolis の 2 種）二グループに区別 し，Eu-panicoideae は，亜鈴形和よび十字形珪酸体を，Chlorideae は両刃の 戦釜形理酸体を含むとした．また，Festucoideae (Aveneae, Agrostdeae, Festuceae, Hordeae) 飞みられる 珪酸体 は, 円形, 楕円形, 矩形などの単純な幾何学的形態であ ると述べている. METCALFE (1956) は, 鞍形珠酸体の 多くが Bambusoideae 飞含まれることを報告した．館岡 (1956) は, 日本産, 北米産执よびインド産イネ科植物 の表皮細胞定観察し,その珪化細胞の形態はPRAT(1936)
の分類記載と同様な結果をえた。

加藤（1960）は本邦のイネ科植物葉身中の珠酸体をま ゆ型, かぎ型, 棒状型, 食パン型に分類し, まゆ型掞よ び食パン型珠酸体は植物種により形態が多少異なること を指摘した。

Twiss et al. (1969) は, Prat, Metcalfe らの植物 学者のこれまでの研究成果をらま克, イネ科植物葉身中 の珪酸体を a) Festucoid Class b) Chloridoid Class c) Panicoid Class 於よびd) Elongate Class 飞大別し, a)〜c) Classは，植物分類グループと密接な関係にある ことを明らかとした．佐瀨・近藤（1974）は，Twiss et al. (1969) の 4 Class 僟動細胞, Prickle hair 由 来の珪酸体叔よびササ属の短細胞に由来する珠酸体を付 加することを提案し (表-1 参照)，この分類法を用いて 本邦に自生するイネ科植物，北海道の現世抢よび埋没火 山灰土壎腐植層の理酸体組成を明らかにした。近藤注か (1983) は，上記の分類をさらに発展させた新分類を提 示した (表-2).この分類ではイネ族由来の短細胞起源 珠酸体をPanicoid Class から独立させ，さら飞各Class を形態的観点から細分する試みがなされている.

大越 $(1980,1982 b)$ は, 短細胞由来の珪酸体の表面 形態洋着目し，それらの珄酸体を食パン状，まゆ状特よ び芓虫（ビスケット）状に大別した。この分類は，まゆ 状（亜鈴形）理酸体の特徵を的確にとらえている点に打 いて評価されるが，名称などが独断的で，既存の分類と の間に混乱を招く .

最近, BROWN (1984) は，北米中央部に自生する 112 種のイネ科植物各部位の植物珠酸体を， I. Plate，II. Trichome, III. Double Outline, N. Saddle, V. Trapezoid, VI. Bilobate, VII. Polylobate, 特よび VIII. Cross 飞大別し，さらに各 Class をごく僅かな形態的差 異によって細分した。しかし，この分類には，土壤中で 比較的多く検出される機動細胞珪酸体を重視して拈ら ず，それらを長細胞珪酸体と同じ Plate Class と包含し ている.

以上の分類は，植物珪酸体の形態を基本として和り， それらに起源細胞特よび植物分類グループを関連づけな がら作成されている，そのため，ややるすると分類基準 に一貫性が乏しいとみなされる，他方，形態物よび起源 細胞のみを基準とする分類は統一性があるが，それのみ では珪酸体の給源植物がわかりづらいと言ら久点があ る.

植生の歷史，古気候の推定など，応用面から植物珪酸 体をみると，それらの分類は植物分類グループとの直接 
表 1 イネ科草本類のグループ別珠酸体組成 $(\%) *$

\begin{tabular}{|c|c|c|c|c|c|c|c|c|c|c|}
\hline 植 & 物 & タダ型 & $\begin{array}{l}\text { ヒダシ } \\
\text { 型 }\end{array}$ & $\begin{array}{l}\text { ダンチ } \\
\text { ク 型 }\end{array}$ & キビ型 & $\begin{array}{l}\text { ウシノケ } \\
\text { グ サ 型 }\end{array}$ & ファン & $\begin{array}{l}\text { ポイン } \\
\text { イ 型 }\end{array}$ & 棒状型 & その他 \\
\hline \multicolumn{2}{|c|}{ ミヤコザサ } & 61 & 1 & & & & 7 & 6 & 18 & 7 \\
\hline \multicolumn{2}{|c|}{ クマイザサ } & 18 & 1 & & & & 35 & 11 & 14 & 21 \\
\hline \multicolumn{2}{|c|}{ チシマザサ } & 37 & 2 & & & & 26 & 10 & 6 & 19 \\
\hline \multicolumn{2}{|c|}{ アズマネザサ } & 34 & 7 & & & & 32 & 16 & 3 & 9 \\
\hline \multicolumn{2}{|c|}{ シホウチク } & 52 & 3 & & & & 27 & 11 & 1 & 7 \\
\hline \multicolumn{2}{|c|}{ カンチク } & 16 & 15 & & & & 37 & 20 & 1 & 11 \\
\hline \multicolumn{2}{|c|}{ マダケ } & 32 & 3 & & & & 45 & 7 & 5 & 8 \\
\hline \multicolumn{2}{|c|}{ オヒシバ } & & 26 & & + & & 6 & 41 & 5 & 22 \\
\hline \multicolumn{2}{|c|}{ シバ } & & 18 & & & & 18 & 42 & 1 & 21 \\
\hline \multicolumn{2}{|c|}{ ネズミガヤ } & & 4 & & 2 & & 20 & 59 & 14 & 1 \\
\hline \multicolumn{2}{|c|}{ ヨシ } & & 29 & 22 & & & 10 & 17 & 7 & 15 \\
\hline \multicolumn{2}{|c|}{ ヌマガヤ } & & 5 & 15 & 51 & & 5 & 15 & 2 & 7 \\
\hline \multicolumn{2}{|c|}{ ダンチク } & & & + & 53 & & 3 & 28 & 2 & 13 \\
\hline \multicolumn{2}{|c|}{ イネ } & & & & 15 & & 57 & 12 & 9 & 7 \\
\hline \multicolumn{2}{|c|}{ ススキ } & & & & 24 & & 22 & 49 & 3 & 2 \\
\hline \multicolumn{2}{|c|}{ チガヤ } & & & & 14 & & 17 & 44 & 4 & 21 \\
\hline \multicolumn{2}{|c|}{ イヌビェ } & & & & 54 & & 10 & 31 & 5 & + \\
\hline \multicolumn{2}{|c|}{ エノコログサ } & & & & 23 & & 14 & 42 & 21 & + \\
\hline \multicolumn{2}{|c|}{ メヒシバ } & & & & 63 & & 4 & 31 & 2 & + \\
\hline \multicolumn{2}{|c|}{ トウモロコシ } & & & & 36 & & 5 & 23 & 2 & 33 \\
\hline \multicolumn{2}{|c|}{ ヤマアワ } & & & & & 46 & & 26 & 24 & 4 \\
\hline \multicolumn{2}{|c|}{ イワノガリヤス } & & & & & 11 & & 41 & 41 & 7 \\
\hline \multicolumn{2}{|c|}{ ハネガヤ } & & & & & 55 & 1 & 30 & 12 & 2 \\
\hline \multicolumn{2}{|c|}{ キツネガヤ } & & & & & 25 & & 44 & 16 & 15 \\
\hline \multicolumn{3}{|c|}{ オオウシノヶグサ } & & & & 32 & 3 & 52 & 13 & + \\
\hline \multicolumn{3}{|c|}{ シバムギ } & & & & 44 & & 50 & 3 & 3 \\
\hline \multicolumn{3}{|c|}{ コムギ } & & & & 45 & & 31 & 16 & 8 \\
\hline
\end{tabular}

* 近藤 $(1983 \mathrm{a})$

的関係，つ李り植物名がわからなければ，十分発揮でき ない，以上のことからも明らかな上うに，各植物と対応 した分類が理想的であるが，同一植物体汇は様々の形態 の珪酸体(例えば,同じタイプでも変異がある，写真図版 V参照)が多数含有されているために，残念ながら植物分 類グループとの関連のみで全ての珪酸体を分類すること は困難である。したがって，現段階では近藤添か(1983) の分類法（表-2）がより有効と考古られる.

今日, 大部分のイネ科植物起源珠酸体はその形態的特 徵により，亜科・属レベルまで区別される、しかしなが ら，Nardus stricta 葉中の分肢状細胞由来の『ト』の字 形珪酸体 (SMITHSON，1958)，イネ葉中の機動細胞起源 珪酸体（藤原，1976a，b ; 藤原・佐々木，1978）は，先 の種特有の形態を示しているため種レベルまで区別され るといわれている，近藤・栄 (1979)，近藤伍か（未発 表）は，イネ科植物起源珠酸体中，とくに短細胞由来の 小型珠酸体の形態打よび乞の粒径着目し，小麦類 $(27$ 種), タヶ・ササ類 (80 種) の属, あるいは種間の違い
を検討し，属，一部種レベルまで区別される可能性を示 した. Uмемото (1973) は, 小麦の野性型と栽培型の間 に, 理酸体の形態, 粒径, 葉中での配列にかなりの違い があることを指摘した。

樹木起源理酸体は，イネ科植物と同様に多種多様な形 態を示すが，その分類は汪とんど報告されていない。

ROVNER (1971) は, 植物珠酸体の古生態学への応用 そついて論じ，その中で体系的な珄酸体分類の必要性を 指摘し，同時飞広葉樹，針葉樹，双子葉草本類，イネ科 草本和よびイネ科以外の単子葉草本類起源珠酸体の形態 的特徴を調べた.

Geis（1973）打よび KLein \& GeIs (1978) は,米国, ニューヨーク州に自生する 23 属 36 種の広葉樹特よび 6 属 17 種の針葉樹葉部の珠化度と珠酸体の形態を詳細 に検討し，それらの樹木起源珠酸体が科・属レベルで区 別されることを指摘した. しかし，樹木起源珠酸体の分 類案については全く触れられていない。

近藤・隅田 (1978), 近藤・ピアソン (1981) は, 本邦 
表 2 イネ科植物起源珪酸体の新分類（近藤 - 佐瀬 · 相馬, 1983)*

I. Orizoid Glass イネ族 イネ, サヤヌカグサタイプ等 2 タイプの亜鈴形

II. Panicoid Class キビ带科, ダンチク亚科, スズ メガヤ巠科の一部

1. 亜 鈴 形 : 1) 短軸 2) 長軸 3) 正常 4) こぶ付き5) フリル付け

2. 複合亜鈴形 : 1) 規則 2) 不規則

3 . 十字形: 1) 薄肉 2) 厚肉

III. Bambusoid Class タヶ亜科（タケ類・ササ類） ミヤコザサ，チシマザサ，メダケ，ホウオウチク タイプ等, 6 タイプの長座鞍形

NV. Chloridoid Class スズメガヤ亜科，ダンチク亜 科・タタ亜科の一部

シバ，コシ，オヒシバ，ニワホコリ，カゼクサ等， 5 タイプの短座鞍形

V. Arundoid Class ダンチク亜科，タケ亜科 2 タイプの長座鞍形

V. Fetsucoid Class イチゴツナギ亜科

1. 長棈円形, 長方形, 力形等, 6 タイプのボー 卜形

2. 3 タイプの帽子形

3. 2 タイプの星状形

VI. Elongate Class

平滑辺棒状形, 刺状辺棒状形, 鋸歯辺棒状形等, 13 タイプの棒状形

VIII. Point-shape Class

$$
6 \text { タイプの矢じり（かぎ）状形 }
$$

X. Fan-shape Class ヨシ，ジュズダマ，シバ，イネ，七ェ，ササ，ネ ザサ，ススキ，オヒシバ，ヌマガヤ等，20タイプ の崩（食パン状）形

X. Club-shape Class

X. Pipe-shape Class

XII. Spine-shape Glass

XIII. その他

* 一部改変

$\mathrm{I} \sim \mathrm{VI}$ : 短細胞に由来する珪酸体. VII : 長細胞に由 来する珪酸体. VIIII：プリッヶルへアーに由来する珪 酸体. $\mathrm{X}$ : 機動細胞に由来する珪酸体. $\mathrm{X}$ ：マク口 ヘアーに由来する珪酸体. XI : ミクロヘアーに由来 する珪酸体．XI：柵状細胞に由来する珪酸体．

に自生, あるいは栽培されている樹木, 55 科 110 属 200 種について, その葉部表皮細胞に由来する珪酸体の 形態を光学および走査型電子顕微鏡で観察し, ヤシ科起 源珠酸体そコンペイ糖状形態の一群, 針葉樹起源珠酸体 を立方体状，板状形態など五群，㕕葉樹起源珪酸体をは め絵パズル状, 五角形状, $\mathrm{Y}$ 字状形態など八群に大別し た。

イネ科植物抢よび樹木起源珪酸体以外の分類は，注之
んど検討されて扔らず，今後の研究課題である.

\section{7. 土壤および地質堆積物中の植物珪酸体}

\section{1）土壤中の植物珪酸体}

植物理酸体は, 土壤の主要構成分ではないが, 大多数 の土壤, とくに表層でごく普通㰸出される.

1866 年, RUPRECHT によって, チェルノーゼムの植 物珠酸体が注目されて以来, 先の存在々意義が多くの研 究者によって報告されてきた。

SMithon (1956b，1958) は RUPRECHTなど西欧の研 究者の業績を総括的に紹介するとともに，英国の牧野土 壤から分離した植物珄酸体を，その地表に生育するイネ 科牧草由来の珪酸体之関連づけ，また家畜賈中にも植物 珪酸体が含まれていることを諗め, 牧野土堙の植物珪酸 体の一部は，家畜の移動抢よび堆鮸肥の施用によって運 搬，供給されることを示した。

BARKER (1959b) は，オーストラリアのビクトリア土 壤から形態の異なる多数の植物珪酸体を分離, 記載し, それらの多くは地表面で枯死，腐朽呿よび燃燒後に，植 物体から放出されたもので, 他のごく一部は動物の萛と して土壌飞持ら込李れること，さらに，植物珠酸体は 雨, 風, 雪などと共に他の地域から運搬されることる述 ベている.

米国では, BEAvers \& Stephen (1958) そよってイ リノイ州のレス土壤から分離した植物珪酸体の特性と分 布が報告され，古土壤の指示者として植物珪酸体の有用 性が認められた。

上述の研究よりやや遅れ, 本邦の土猿, とくに火山灰 土壤から分離した植物珪酸体の分布, 形態, 特性などが KANNo \& Arimura (1958b), 加藤 $(1958,1960)$, 有 村・菅野 $(1965 \mathrm{a} ， \mathrm{~b}) ，$ にょって報告された。

土㙴中の植物珪酸体量は, ある地域から他の地域氻 けてはもちろん，同一地域内でもかなり幅広く変わる が, 地理的要因よりも植物種, 土壤条件, 気候, 地形, 珪酸体の 安定性など多くの 要因が 相互に 関係している (Jones \& HaNdrek, 1967 ; Wilding \& Drees, 1968, $1971,1974)$.

植物理酸量の評㯈は, どの範囲の粒径試料から分離し たかによって変わる。一般には風化抵抗性の強い珪酸体 を多く含を $20 \sim 50 \mu$ 粒径試料が用いら就ている（JoNES \& HAY, 1975). しかし, 土境によっては, 珃酸体精 径にかなりの幅がみられる。例艺ば，西オクラホマ州の Ustolls (乾燥地带のブルニゼム), ミネソタ州の Udolls (湿潤地帯のブルニゼム) 中の植物珠酸体の $2 / 3$ 以上は 


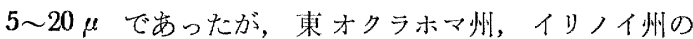

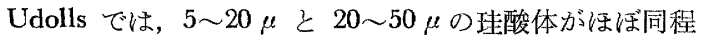
度含委れていた (Jones \& BeAVERs, 1964a ; VERMA \& Rust, 1969 ; YEGK \& GrAY, 1972).

一般に, 土壇中の植物珪酸体量は乾土当たり $<0.1 \%$ 〜3\% (平均 $2.5 \%$ 以下) の範围にある (GEIS \& JoNES，1973）とされているが，きわめて高含量を示す土翌 がある. 例光ば, RIQUIER (1960) はインド洋上のレ・エ ニオン島のアカシア, バンブー, コケ, シダなどの植生 下に発達するポドソル様土壌の漂白䁌 ( $\mathrm{A}_{2}$ 層) の汇と んどすべてが植物珄酸体であることを報告した．NORGREN (1973) は，オレゴン州に和いて植物珪酸体が 20 $\%$ 以上含有する草原土堙を見出している. 本邦に括い $\tau$, Kanno \& Arimura (1958b) は火山圧土壌の 20 $200 \mu$ 粒径試料の 30 ～ $60 \%$ が植物珠酸体であることを 報告した. また，東海地力の黒ボク土表層には乾土当た り最大 $16 \%$ の植物珠酸体が含有されていた（加藤， 1960). 北海道から九州に分布する火山灭土壤腐植層 （埋没層も含む）の植物珠酸体は各地域によって違いが あるが，0.3〜 17\% の範囲（181 試料の平均は，3.8\%）

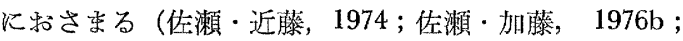
近藤，1982a，1983b)。これらの值は，㘯る限られた粒径 （例穵ば, 20〜50 $\mu, 10 \sim 100 \mu$ ) に基づいて算出されたも のであるので，土壤中の植物珪酸体総量は少なく見榬っ てもその 2 倍以上になる(VERMA \& RUST, 1964).この 概算は，前記の Jones \& BeAvers(1964a) および GeIs （1973）によって報告された植物珠酸体の椟径分布に基 ついている.このように，土䁃中で高い植物珪酸体量を 示す理由は，遊離の球酸を多量に富む东材の土境上飞珪 酸植物が成育することと関係あるといわれている(WILDING et al., 1977).

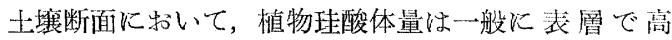
く，下層に向かって漸減する，植物珪酸体が確認される 深さの下限は埋没層索除くとほぼ $50 \sim 100 \mathrm{~cm}$ である (Jones \& BeAvers, 1964a ; Witty \& Knox, 1964 ; Wilding \& DrEes, 1968). この植物珠酸体の深度分布 は, 植物被によって異なり，森林土燷に比べ草原土壤で より下層まで達している。

累積テフラやレスを母材とする土㖶断面では下層で植 物珠酸体の極大值が得られることがあるそそれらの曆準 は，炭素含量もとこで極大值を示すことが多いので，テ フラおよびレスの堆積静止期あるいは静緩期の古土㗒 表層と推定されている（加藤，1963，1977；VERMA \& Rust, 1969 ; Norgren, 1973 ; Wilding et al., 1977).
このような埋没土缺の確認は，埋没過程中になんらかの 原因で有機物が消失した際により有効な方法といえよ 5 .

植物珪酸体量は，土壤有機物（または，炭素量）と正 の相関関係がある（菅野，1961；加藤，1962，1963， 1977 ; 佐瀬 - 近藤, 1974 ; 佐瀨 - 加藤, $1976 \mathrm{~b}$; 近藤, 1983a)．この事奏は，植物珪酸体の供給源である植物が 腐植形成に関与していたことを示唆する.

佐瀬・加藤 (1976b) は，本邦の火山灰士猿腐植層の 植物珠酸体量と有機炭素量との関係をタケ・ササ類を珠 酸体の給源植物とするグループと，それ以外のイネ科草 本類を給源植物とするグループに分け検討した。そとの結 果, 植物珪酸体量と有機炭素量との間には有意な正の相 関関係がとれどれあったが，有機炭素量/植物珪酸 体 量 比に違いが譛められた.この違いは植物種の珄酸体含量 の差に起因し、ササ・ネザサ類が腐植の主要な給源植物 の場合には，ス大キ類が腐植給源植物の場合よりその比 が小さくなることを子測した。

植物珪酸体量は，土壤採取地点に括ける自然の生産力 を反映するものとみなされている。

例光ば, Jones \& BeAvers (1964a) は,イリノイ州の ブルニゼム土壤分布域に発達するカテナ土堙の植物珄酸 体量を調べた結果，排水中程度の土壤が最も多いことを 諗めた。このことは，イリノイ州中西部において Andropogon gerardi Vitman の生産量が排水中程度の土㙞で 最も高いこと（AleXANDER et al., 1968) と良く一致し ている. 同様な結果は, 北海道, 十勝地方の火山灭由来 のカテナ土壤に扣いても確認されている（近藤・太田， 1979).

翼なる植生下の土壤から分離した珠酸体量は，森林植 生より草地植生下の土壌に氺いて明らかに多いことが示 された (WILDING \& DREES, 1971).これは，草地の 主要構成種がイネ科植物であるためである. WITTY \& KNOK (1964) は，隣接する森林牤よび草地土壤の植物 珪酸体量 $(15 \sim 100 \mu)$ を調べた結果，草地土壤が約 10 倍以上も多く含有していることを報告し，過去数千年間， 森林と草原の分栛が玨とんど不変であったことを推測し た。

WILDING \& DREES (1968) は，才ハイオ州中西部の 漂碩堆積物上に発達する土壇の植物珪酸体量を調べ，ブ ルニゼム土㙵は灰褐色ポドソル土塞の 4 倍珠酸体量を含 有していることを報告し，草原の影響安受けた年数はブ ルニゼム土壤では平均 1,250 年, 灰褐色ポドソル土㙵 では 250 年であると推浿した。 さらに，WILDING \& 
DREES（1971）は，現在草原下にあっても植物珄酸体量 が少ない所は最近まで森林植生の影響下にあったと主張 した。しかし，林床にササをともならことの多い本邦の 森林土壤は植物珄酸体量が高くなると予測される。した がって, 植物珠酸体量の多少だけから植生の違いを論ず ることは危険である。

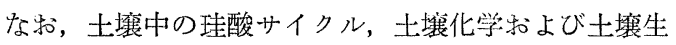
成に植物珪酸体は重要な役割を演じているが，この方面 に括方研究 (WILDING \& DREES, 1974; BARTOLI \& Selmi, 1977 ; Bartoli \& Souehier, 1978 ; Anderson, 1979 ; Bartoli et al., 1980 ; ANdRejWeko, 1983 ; BARTOLI, 1985) は極めて少なく, 今後早急に解決すべ き課題である.

\section{2）地質堆積物，その他に含有する植物珪酸体}

植物珪酸体がいずれの年代までさかのぼって堆積物中 に残存するかは, 地質学扣よび古生物学を専攻する研究 者の関心時である。

微化石としての特徵を備光ている植物珪酸体は, ウイ スコンシン氷河期のレス抢よび漂磞堆積物 (JONES et al., 1963 ; Jones \& Beavers, 1964a; Wilding \& Drees, 1968), 新生代拉よび中生代の堆積物 (BARKER, 1960d), 第三紀の堆積物（JONES, 1964 ; BARKER, 1960c ; GILL, 1967）特よび白亜紀の頁岩（JoNEs et al., 1963）から検 出されている.

最近, Retrallack (1984) は, 生態系㧍よび土壤発 達の中で，古土壌に含有される各種化石が酸化還元， $\mathrm{pH}$ などの物理化学的要因により変化する過程をモデル 化し, 時間経過拉よび酸性の増加に伴い植物珠酸体のみ が究極的に Ultisol あるいは Spodosol 中に長期間保存 されることを推定した。

李た，植物理酸体は空気塺（BARKER，1960d；FOLGER et al., 1967; Twiss et al., 1969), 雨 (BARKER, 1959b), 動物の蕒 (SMITHSON, 1958; BARKER, 1959b; JoNes \& HANDREGK, 1967), 深海. (Folger el al., 1967 ; MikKELSEN, 1984) 中でも発見されている.

地質堆積物中の植物珄酸体の研究は, 土壤中の气礼炕 此べ情報が極めて息しい，今後，この方面からのアプロ 一チが必要と思われる。

\section{8. 植物珪酸体の応用}

一片の植物葉から抽出される植物理酸体は, われわれ が評価している以上に利用性に富み，その灾用籁围も犯
表 3 植物珪酸体分析の灾用*

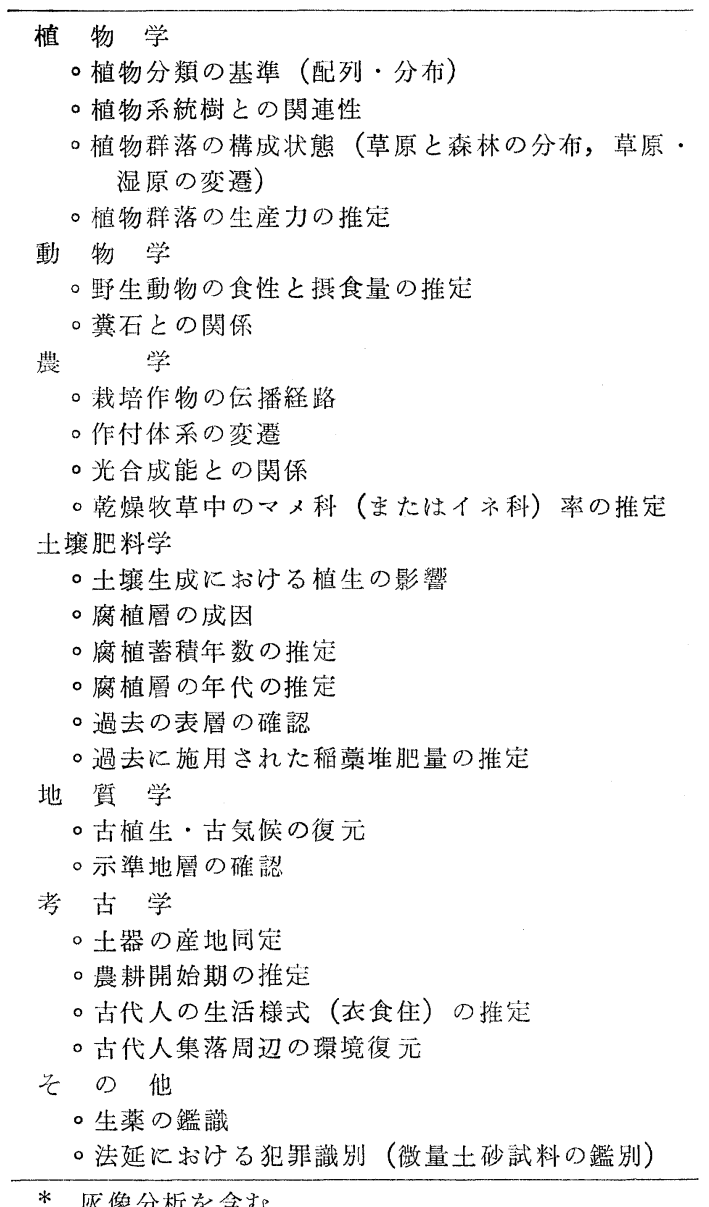

罪捜查の物的証抛のきめてとなる微量土砂試料の鑑別か ら動物の翼分析にいたるまで各分野から注目されてい る.

植物珪酸体の応用は，植物珄酸体をどのよらにとら克 るがよって二大別される。すなわち, 一つは植物理酸 体そのものを物質的飞利用することで㐫り，他の一つは 植物珪酸体のもつ形態的特質を利用寸ることである. 前 者の例としては, 植物珪酸体の高い珪素含有量飞着目 し, 薬品处理によって低コストの理酸化合物（例总ば, 四塩化珄素）を生成し，IC，光ファイブァーなど先端技 術の担い手であるシリコンの原料源としての利用が試み られていることがあげらるる5)。後者の例としては, 植 物理酸体の量叔上び種類を調べることによって, 稙生の

5）北海道新聞，1985年 6 月 4 日による.

工業技術院道開発試験場はイネのモミガラからシりコンを取り出す技術を開発，実用化をめざしている. 
状況特よび環境を復元する植物理酸体分析法があげられ る.

ここでは，植物珪酸体分析の面から，各分野への応用 そついて紹介したい.

表-3 は，これまで植物理酸体分析で沁用されている 研究，あるいは発展可能な研究項目を列記したものであ り，今後ますます植物珪酸体の活用が期待できよう.

\section{1) イネ科稙物の同定・分類}

植物学への貢献は, 珪酸体が植物分類, とくにイネ科 植物の分類指標に用いられていることである. 植物葉表 皮細胞の植物珪酸体の形態, 分布, 配列などを調べる研究 は, PRAT (1936，1960) はじめ多くの植物学者の伝統的手 法となっている。例觉ば，本邦に打いて大木（1927-30) はこの力法を適用し，多くのタケ・ササ類の兏像を钼祭 し, 表皮細胞中の短細胞, ブリッタルヘアー、ミミロ アー, 機動細胞の配列, 粒径などを記載し, 分類してい る.このよらな灰像法による手法は，本邦のイラクサ 群 (佐竹, 1929-30)，コムギ・オオムギ（加藤， 1932, 1933) の分類学的研究执よび薬用葉の鑑别 (小原・近藤, 1929，1931；近藤，1931）飞適用さ机た.

館岡（1956）快，日本産，インド産拈よび北米産の久 ズガヤ巠科, キビ亜科葉身 114 種の 解剖学的特徵を検 討し，その中で表皮細胞中の短細胞由来理酸体の形態が PrAT の記載 (Panicoid, Chloridoid subtype) と一致 し，Festucoid type のものは全く認められなかったと述 ベている.

STEWART (1965) 《野生動物の垂特よび胃の内容物の 構成を同定するための基礎研究として, 東アフリカ(ケ こヤ) に自生するイネ科植物 57 属 163 種の植物理酸 休を検討した。

BLACKMAN (1971) は，カナダ南アルバータ州の牧草 地のイネ科植物 26 種について, 植物理酸体の形態と分 布を詳細に検討し，それぶイネ科植物の同定沶よび分類 のための予備調査に有益であることを示した.

上記の研究は，いずれも破片扣よび外形では鑑別困難 な植物葉をその植物玨酸体の形態，配列，分布から同定 しようとしたものである。このような方法は，薬用学に 特いても用いられている。例穴ば，漢方薬は色々な植物 の葉，茎，樹皮，根あるい恨荎を断片化し混ぜ合わぬ ているため，外観から同定することは困難である．天然 薬の輸入業者はそれが混ぜ物か天然のものか十分熟知寸 る必要がある.このようなことから, Uмемото \& HozUMI（1973） は中国で伀統的に用いら就ている利尿剂 “Dan-zhu-ye” にどのような植物が混入しているか植
物珪酸体の形態と分布から検討し，とれらがササクサ (Lophalherum sineses) あるいはその類縁イネ科植物であ ることをつきとめた。

\section{2）栽培作物の伝播}

栽培作物がいつごろ本邦に伝播したかは，農耕文化の 成立を知るら光で極めて重要なことである.

稻作は, これまで考古学遺跡の炭化植物遺体, 炭化種 子の厕像分析から弥生時代以降の存在が 実証 (WATANABE，1968; 渡辺，1981) されているが，さらにどのく らいまで年代をさかのぼるかについては推測の域を脱 していなかった。藤原 $(1974,1976 \mathrm{a}, \mathrm{c}, \mathrm{d}, 1979$, 1980，1983，1984）は，イネの機動細胞理酸体の形態に 着目し，多くの弥生扎よび縄文時代の遺跡土裹とそれに 伴う土器胎土中からイネ機動細胞珪酸体を検出した。 そ の結果, 本邦に㔚汀る稲作の歷史は少なくとも縄文晚期 までさかの汸ることが央証された。また, 藤原・佐々木 (1978) 牥イネ機動細胞珪酸体の大ささ・形状を11 種 23 系統について検討し, 日本稲と外国稲との間に巽な る傾向が尔ることをつきとめた。しかし，一部例外るみ られ，それらは『仙』などの中国稲を含んでおり，日本 稲の渡来経路に中国稲がなんらかの形で関与していたこ とが推測された。

一方，イネ以前の原初農耕として，上エ，アワなどが 截培されていたとの仮説（石田・泉，1967）が以前より 晿兄られていたが，松谷 (1981a，b) は，この仮説を実 証すべく縄文遺跡出土の小型炭化種子执よびパン状炭化 物の灰像分析を検討した. しかし，ヒエ，アワは弥生時 代のものから検出 (WATANABE, 1970 ; 渡辺, 1981) さ れているが，縄文時代からは今のところそれと断定でき る証拠は確認されていない。

最近，佐々木 (1984) によって，燒畑農業の存在を機 動細胞珄酸体を用いた方法で実証しようとする試みがな され，現在も依然として焼烟農業が特こなわれている宮 崎県椎葉村の向山土壤を対象として分析がなされた，兑 の結果, キビ族の機㲜細胞珪酸体が多量に存在する地点 $\left(25 \times 10^{8}\right.$ 個 $/ \mathrm{m}^{2}$ 以上) とが明らかになり，このような手法によって古代遺跡周 辺の焼烟範围が推定可能であることを示唆した.

中国では，イネ，アワが約 5,000 年前に既に栽培さ れていたことが土器胎土に含まれる植物遺体の灰像分析 によって実証されている(EdMAN \& SöDERBERG，1929). 同様な网像分析による研究は，近東抒よびョーロッパの 遺跡出土の炭化パン括よび土器胎士に適用され, それら からはオオムギ，コムギ，ライムギなぞが検出された 
(Helbaek, 1952, 1959, 1961).

中央アメリカでは，トウモロコシの過去に拈ける栽培 の事実を，短細胞由来の十字形拄酸体の粒径およびその 比を利用して立証した例が報告されている(PEARSALL, 1978, 1980, 1982 ; Piperno, 1980).

PeArsall (1978) は，エクアドルのサンタ・エルナ半 島の考古学遺跡 (Real Alto) 土壌からトウモロコシに 特有な $16 \mu$ 以上の十字形珪酸体を検出した. 寸なわ ち, 遺跡土壤の十字形珪酸体の頻度分布は, エクアドル のイネ科野草（ガマグラス属, クリノイガ属, オヒシバ 属）のそれより，むしろトウモロコシの 9 系統の平均値 に近似していることをつきとめた，その後，PEARsalL （1980）は多くのイネ科野草，遗跡土壤牞よび表層土猿 を追加検討し, 十字形珪酸体の 4 カテゴリー（小, 中, 大, 特大）の頻度分布がイネ科野草に比し，代表的上り モロコシのとれに一致することを考古学土壤試料から実 証した. 一方, 表層土壤の十字形珪酸体の頻度分布はイ ネ科野草のそれと酷似していた。これらの結果は, トゥ モロコシ栽培が Real Alto 遺跡に和いて当時すでに存 在していたといら仮説（LATHRAP et al., 1977）を支持 した. PiPERNo (1980) は, パナマの遺跡に前記の方法 起適用し, 中央パナマ太平洋岸地域に打けるトウモロコ シ栽培 $(2,500 〜 1,000$ B.C) の存在を夹証した. 非イネ 科栽培植物（例えば，ショクョウカンナ，キャッサバ） に由来する珪酸体の同定は PEARSALL (1980) 怙よび PIPERNo (1981) Kよって試夕られているが，まだ研究ば 不十分であり, さらに, それらの分類执よび生態的な関 連性を十分検討する必要がある。

な拉，作付体系の変遷（例えば，乾燥農業に括けるか んがい，熱带農業に拈ける盛り土拈よびうね立て技術な ぞ）を究明する手段として植物珪酸体は, ハワイ島, 中 央アメリカ, ペルー, シリアの遺跡土壤で適用されてい る (Turner \& Harison, 1981 ; Miller, 1980 ; PeArsall, 1982 ; Pearsall \& Trimble, 1984).

今後, この種の研究発展が大いに期待されている.

\section{3）考古学遺物の同定}

植物珠酸体は，酎熱性に篦んでいるため，花粉扣よび 植物遺体が殆ど見い出せない烧上括よび土器胎土からる 検出される場合が多い。そこで，この性質を利用して， 考古学遗跡の焼土物よび兏の植物珪酸体分析から, 古代 人がどのような植物を燃料として用いていたか，亦た， それらを供給した遗跡周辺の植生はどのようであったか など，貴重な情報が得られる。

このような見地から，加藤（1975）は，愛鷹山麓に位
薑する元野遺跡（縄文早期後葉）の焼土とその下の黑土 層の植物珪酸体分析を行い，いずれの試料もタゲ型が日 倒的に多くキビ型がこれに続く組成を示した。たた，雨 試料で異なる点は珪酸体量が焼土試料で明らかに富加 $(650 \mathrm{~kg}$ ないし $1,100 \mathrm{~kg})$ していたことである.この ことは，古代人が遺跡周辺に生育していたタケ・ササ類 などのイネ科植物を燃料の一部として用いていたことを 示している.同様な結果は，八王子市手天橋遺跡（縄文 早期後葉）䍇よび多摩ニュータウン遺跡（縄文前期後葉） の焼土，ならびに黒土層の植物珪酸体分析に括いても得 られている (近藤，1981；佐瀬，1984). 佐瀬 (1982) は， 多摩ニュータウン遺跡（古墳時代）の燒土を分析し，接 土試料は同時代の対照土壤に比べて, 理酸体量が多く, かりキビ型が多いことで特街づけられた。このようなこ とから，人スキなどのキビ带科植物が選択的に然料とし て使用された可能性を指摘した。

大越 (1982a) は，千葉県栄町能角寺ニュータウン遺跡 (縄文中期) 飞敃いて多数の焼土を分析し，夕ヶ類，州サ 類に由来するタケ型が圧例的に多いことを認めた。亦 た，平安時代のカマド試料では，縄文時代と異なるス久 キなどに由来ずるキビ型が多く検出された。ただし，こ れらの結果は，対照土裹を検討せず，焼土試料から分離 した珠酸体を全て扊に由来したものとして取り扱ってい る。しかし，焼土には焼成前の土壤も当然混入している ので，それらに含まれていた植物珠酸についても十分考 虑し，焼土周辺土壤を対照として分析すべきであらう。

土器胎土中には，しばしば植物珪酸体が検出される が，これは古代人が土器製作時に粘土の中につなぎをよ くするなど,なんらかの目的から植物繊維を混入した か，㘯るいは素地自体にすでに植物珪酸体が混入してい た場合の二通りが教えられる（上條，1984）。前者であ れば植物珪酸体分析から混ぜた植物種が判明でき, 後者 であれば粘土採取地などの座地同定が可能である。

土器胎土の植物珪酸体については, 熊本県の各期縄 文土器のイネ機動細胞珪酸体を探索した藤原（1980， 1984), 神奈川県海老名市上浜田遺跡産出の繊維土器を

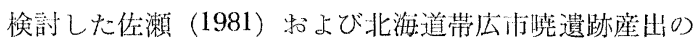
繊維土器を検討した近藤・佐藤（1985）の報告がある. 前述した佐瀬（1981）の分析結果からは繊維状物質の給 源は不明確であったが，近藤・佐藤（1985）の結果はサ サ属を混ぜた可能性が指摘された。最近，近藤㭱ふ(未発 表）は, 栃木県産出の土師器の植物珪酸体分析を行い, 土袞腐植層に匹敵できるほど多量の珪酸体を含む例，な らびに産出の違いにより理酸体組成がかなり異なる例を 
見出している.

ヨーロッパでは, 昔からつり鐘鋳造の際, 粘土に牛糞 を混ぜて用いることが今日でも習慣として残っている. イギリスの 13 世紀の礼择堂遺跡から出土したつり鐘鋳 造器の破片中からイネ科植物起源の珪酸体が見出されて おり，つり鐘鋳造の際に粘土の補強に家畜の贑を用いて いたことが実証された（CUTLER，1978). これは，植物 珪酸体が溶融した鐘青銅によって粘土の中で熱せられて も，その耐熱性のため残存した例である.

古代の家畜(有踣類)がどのような慨を食べていたかを 知る方法として, 遺跡出土の歯に付着，あるいはエナメ ル質間に埋藏した植物片の植物珪酸体分析が用いられ， 環境考古学の分野に広く適用される可能性が ARMITAGE (1975) によって指摘された。

以上，述べてきた以外にも，植物珪酸体の考古学遗物 への応用は石器に付着している植物片, 草ぶきの壁や屋 根, 履物, 編物, さらに食料の貯蔵庫, 脱穀場などにも 適用されよう.

\section{4) 土堙と植生の関係}

土壤学に和ける植物珪酸体の寄与は, 土壤生成因子と しての植生の影響を知る手がかりを与えてくれることで ある.このような情報は, 本邦の火山灰土壌, 埋没腐植 層和よび古土畩の生成, 分類を研究するに当たって極め て有益である。

周知のように，本邦に分布している火山灰土壇の表層 は，独特の黒い色を呈して拈り，そのため火山灰土㖶を 黒ボク土あるいは Andosol (暗土) とも呼んでいる（加 藤，1983)．この黑ボク土腐植層の成因については, 従来 からススキなどの草原植生が密接に関係しているとの考 总(山根, 1973) があるが, 実証には至っていない。 のことを解決するには，腐植層中の植物珄酸体分析が有 効である・

望野・有村 (1958a), 加藤 (1960) は, 植物珪酸体の 形態からササ，ススキ, チガヤなどが主要な給源植物と 推測した. その後, 本邦各地の現世和よび埋没黒ボク土 腐植層の植物珪酸体組成が，佐瀬・近藤 (1974), 佐瀬・ 加藤 (1976a) おょび近藤 (1982a) によって検討され, 北海道ではササ属, イチゴツナギ車科, 東北・北関東・ 中部ではキビ亜科, ササ属, 関東・東海・中国・九州で はメダヶ属 (主にネザサ)，キビ带科が完新世をつらじ て，黒ボク土の腐植給源植物であることが示された。 こ のことは, 黒ボク土の腐植給源植物としてススキを重要 視した前記の説と異なり，気候帯により異なっていたと
いら多元説を示唆している.上記の珪酸体組成から推測 された草地植生は，Numata (1969) により明らかにさ れた本邦の半自然草原植生分布と非常に良く一致し，與 味深い。

な拉，九州大隅半島以南の火山灰土腐植層中には，イ ネ科植物起源珪酸体よりタブノキ，スダジイ，イスノキ などの照葉樹林に由来する樹木起源珪酸体を多く含も例 が観察され，それらの土壤は概して腐植含量が低い傾向 にある(近藤，1982b)

黒ボク土の分布範团の中で，植被の違いで全く性質の 異なる土壤が生成される場合がある。すなわち，黑ボク 土は草原植生下に限られ，ブナ林など森林植生下では褐 色森林土的土壊が生成されるといわれている（山根， 1973)。佐瀨ほか（1985）は，富士西麓和よび天城山地 に分布する植生以外の土壤生成因子がほぼ同一の黒ボク 士と褐色森林士の植物珪酸体分析をおこなった結果, 黒 ボク土はキビ亜科，イチゴッナギ亜科などの草原植生， また，褐色森林土はササ属孝林床に伴らブナ植生，拉よ び常緑ガシ植生下でそれぞれ生成されたことが示唆され た. 永塚 (1984) は秩父地方に执いて佐瀬はか(1985) と 同様な見地から二つの土壤の植物珪酸体を検討し，褐色 森林土には常緑ガシに由来する樹木起源理酸体が多量に 含まれていることを明らかにした，河室 (1981，1983a) は, 長野県黒姫山括よび十和田八甲田山に分布する火山 灰由来の褐色森林土之黒色土の 植物珪酸体組成を検討 し，褐色森林土ではササ属，黒色土ではススキがそれら の生成に関与していたことを推測した.

ニュージーランドの Andisol6) 腐植層中には, 樹木木 部起源およびシダ類起源の珪酸体が多数含有され，本邦 の黒ボク土の植物珪酸体組成と異質であることが佐瀬注 か (未発表)によって示された。このことは，腐植の特 性を考慮すると両国の黒ボク土の生成に植生経厢が何ら かの形で関与してきたことを暗示し，大変興味深い。

九州 ·沖縄・西南諸島に分布する赤黄色士は, イスノ キ，タブノキ，スダジイ，常緑ガシに由来する樹木起源 珠酸体によって特徽つけられ，小笠原諸島の赤色士はヤ シ科・イスノキ起源理酸体で特徵づけられることが近藤 (1975b) によって報告された.ささらに，近藤 (1984b) は，それらの珪酸体が全珪酸体の 10〜30\% 以上を占わ る場合，森林植被の影響が大きいことを指摘した。

ブラジル・アマゾン川流域に分布する黄色ラトソル。 腐植質黄色ラトソル土壤は, ヤシ科起源のコンペイ糖状 珪酸体を多数含んで扔り，それらはヤシ科植物を優占す

6) 火山灰土分類国際委員会 (ICOMANDO) による分類. 
る植生下で生成されたことが推測された。また，腐植質 黄色ラトソル土は, 黄色ラトソル土よりイネ科植物起源 珪酸体を多く含有して拉り，腐植集積に人為作用ととも にイネ科植物が関与していたことが示唆された (KONDO $\&$ IWASA, 1981).

REQUier (1960) は，アフリカ東部のレ・ニニオン島 の玄武岩母材の熱帯土壌に抢いて，ポドンル性の灰白層 $(5 \sim 30 \mathrm{~cm})$ のほとえどがアカシア， バンブー， シダ， コケなどに由来する植物珪酸体であることを見出し，そ れらの珪酸体が著しく集積したことにより生成した疑似 ポドソルであることを明らかにした。

近藤・小崎 (1986) は，過湿潤から半乾燥地带に分布 する西アフリカの低地土壌の植物珪酸体分析を和こな い, それらの土壤にはキビ型㧍よびュンペイ糖状珠酸体 を普遍的に検出されることを見出した，悉た，気候，地 形などによって珪酸体組成に特徵がみられ，一般に乾嚳 地带ほどイネ科植物起源の理酸体が多く, 湿潤地帯に向 かって樹木・ヤシ科起源珠酸体が多く検出された.さら に, ヤシ科起源珪酸体は, 氾濫原, 断層低地に打いてそ の出現頻度が低く, 小規模な内陸谷で高い傾向にあっ た.

植物珪酸体は, 低湿地の土䖯の堆積様式拉よび生成環 境を推測する指標として極めて有効である。例えば，低 湿地土壤の黑色士層の起源判別に植物珠酸体の組成を観 察することで, 黒ボク土の腐植が流入再堆積したものか, 泥炭が分解したものかを鑑定できる(加藤, 1977).さら に, 植物珠酸体分離の際に混入する珪藻预よび海綿骨針 などを併せて考察すると，一層堆積環境が明瞭にされよ う(梅村・近藤, 1984).

泥炭あるいは泥炭土がどのよらな植物から構成されて いるかは，泥炭土の生成・分類および理化学性を知る上 で重要であるが，慣例化されている肉眼観察による植物 同定は植物学的知識と熟練を必要とするばかりでなく, 分解のすすんだ泥炭土には適用でさない（近藤，1980）。 このようなことから，近藤・原田（1980）は，泥炭地植 物之泥炭土の植物珪酸体を検討乙, 肉眼判定の出来ない 植物の同定が可能であることを指摘した。また，乾燥化 による泥炭地の環境変化は泥炭地飞進入するササ属の珪 酸体を同定することで推測可能である.

以上のように, 植物珠酸体分析は土壤と植生の関係を 知るう壳で有効な手段といえよう。

\section{5）草地植生の变遷}

植物珪酸体の植物生態学への応用は, 過去に何度もイ
ネ科植生が変化したような場所で発揮される。

本邦に広く分布する黒ボク土は，まさにこの条件にう ってつけとい光よう。

黒ボク土は，火山活動による降灰と土壌生成の繰り返 しによって多数の腐植層を累積しているが，それらの腐 植層の植物珪酸体組成を調べることで，イネ科植生の歴 史が究明できる.

各地の累積性黑ボク土断面に見られる埋没腐植層の植 物珪酸体分析に上れば，今日の半自然草原植生分布の成 立は約 8,000 年前にさかのぼれそうである(近藤, 1982a). それ以前では黒ボク土的埋没腐植層は関東以北では確認 されず，関東地域でも退色した暗色帯として見られるに すぎない,一方, 東海, 九州地域では, 依然として明瞭 な埋没腐植層が存続している。このような地域差は，1 万年以前の寒冷気候の影響を無視して考えることは出来 ないであろう。

北海道に和いては，8,000 年以前は現世の主要構成種 であるササ属が添とんぞ姿を消し，イチゴツナギ互科優 占のイネ科植生が成立していたと思えれる（佐瀬・近 藤, 1974 ; 近藤, 1982a).

十勝地方の居辺 16 遺跡土壤の植物珪酸体分析 (近藤, 1985) によれば, 約 19,000 年前の先土器包含層でウ シノケグサ型珠酸体の割合はピークに達する. ウシノケ グサ型の給源植物であるイチゴツナギ亜科は寒冷地型イ ネ科植物（C3 植物）であるので，その珪酸体の割合の 増加は, 気候寒冷化のバロメーターの一つと考光られて 扣り（佐瀬・近藤，1974；佐瀬，1980c)，2万年前後が ウルム氷期の最寒冷期とされていることと前記の結果は 良く一致している. 前述の包含層下位の先土器正包含層 (約 32,000 年前) 7 亿打いてタケ型拄酸体が出現し, 気 候の緩和が示されるが，その割合はウシノケグサ型より 明らかに小さく，また，ポイント型がファン型より多い 特徴から,この時代は現代よりやや寒冷な気候であった と推測される.このような 1 万年以前のウシノケグサ型 珪酸体によって特徴づけられる分析結果は, 十勝地方の 多くの土壤および遺跡土壤断面で得られた結果と一致 する（近藤・太田, 1979 ; 近藤, 1985 ; 近藤・佐藤, 1985).

東北, 八戸周辺地域で行った植物拄酸体分 析の結 果 は, 約 8,500 年前に堆積した南部浮石層直下の 埋没腐 植層までは現在と同じキビ亜科優占のイネ科植生であっ た (佐瀬 ·加藤, 1976a ; 佐瀬, 1980a). 一方, 約 13,000 年前に堆積した八戸浮石直下の埋没腐植層では, ウシノ

7) 过 秀子氏よりの私信 $\left({ }^{14} \mathrm{C}\right.$ 年代測定值). 
ケグサ型，ポイント型，棒状型珪酸体の割合が増加し， イチゴッナギ亜科がイネ科植生の主要構成種であったこ とが示された（佐瀬，1980b)。また，同時にこれらの層 準で，モミ属など針葉樹起源珄酸体が多数検出され，当 時この地域は亜寒帯針葉樹林が広がっていたことを物語 っている.この結果は，大池汪か（1977）による花粉分 析の結果と矛盾していない，八戸浮石層下位に累積する 高館テフラ層のらち，約 25,000 年前江推積したと推測 されるビスケット浮石直下の埋没土まではウシノケグ サ型の割合が高く，イチゴツナギ亚科優占のイネ科植 生が推定された（佐瀬，未発表)、八戸浮石から合同浮 石が 堆積した時期は最終氷期の Upper Pleniglacial (平川，1975）飞対此可能と考壳られる. 合同浮石層よ りさらに下位の高館テフラ層は全般にタケ型の割合が高 く，ササ属優占のイネ科植生が推測されるが，オレンジ 浮石の層準ではキビ型の割合が増え，アオスジ浮石の㬝 準ではウシノケグサ型の割合が増加する．前者は気候の 温暖化，後者は寒冷化を意味するるのと思われる.

東京都練馬区成増, 多摩丘陵拉よび埼玉県浦和市大宮 台地の関東ローム層の植物珪酸体分析 (佐瀬活か, 1982 ; 細野・佐瀬, 1985 ; 佐瀬, 未発表）火上ると, 表層はネ ザサなど，タッ類に由来するタケ型（以後，タケ亜型と 呼ぶ）の割合が高く，かつキビ型るかなり検出されるこ とからネザサ節，キビ亜科を主体とするイネ科植生であ ったと思われる．表層下部からは植物珠酸体が徐々に変 化し, ササ属に由来するタヶ型（以後，ササ亜型と呼ぶ） の割合が増加する。これは，暖温带イネ科植生から冷温 帯イネ科植生への移行を示するのであろら．立川口ーム 層はササ亜型の 割合が高いことで特徴づけられる。同 様な結果は，府中市幸町の関東口ーム層飞和いて近藤

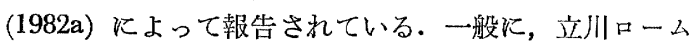
層の暗色帯は温暖期の埋没腐植層と考学られているが (松井ほか，1968），とのことを示す植物珠酸体組成の変 化は認めら礼ない：委た，立川口ーム層には，最終水期 の最寒冷期と考光られる 2 万年前後の層準も含まれてい るが，それを示す植物珠酸体組成の変動す全く認められ ない，したがって，立川期はササ属の優占する冷温帯草 地植生が成立し，継続した時代と考兄られる。

武蔵野ローム層では，穴の上部層準に跲いてタケ亜型 の割合が增加するネザサ主体のイネ科植生が 推定され る. 一方, 武藏野ローム層下部を特徵づける東京軽石の 層準 $\left(4.9 \times 10^{4} \pm 5,000\right.$ F.Ty.B.P., 町田·鈴木，1971) では, ウシノケグサ型, 棒状型，ポイント型珠酸体の割 合が増加し，気候の寒冷化に伴らイチゴッナギ亜科を主
とするイネ科植生の成立が示される。立川，武蔵野ロー 么層をと抗して，寒冷型イネ科であるイチゴッナギ亜科 の勢力拡大が示されるのはこの層準に限られるので，関 東地域は一般に最寒冷期とされている 2 万年前より，む しろ 5 万年前後が寒彾で西った可能性が大きい。この上 うな関東地域の二つの寒冷期の植生の差については, 相 模地域の大型植物化石・花粉化石群集を詳細汇検討した Tsuj1 et al. (1984) 飞よっても同様汇指摘されている. 武藏野ローム層の植物珠酸体分析はまだ十分といえず， 異なった地点に和汀るデータの集積が必要である.

九州地方の植物珠酸体 分析の結果 (佐瀨・加藤, $1976 \mathrm{a}$; 近藤，1982a，b) 飞よると，約 9,000 年前まで は関東地域と同様にネザサ，キビ亜科を主とするイネ科 植生が支配的であったが，それ以前 2 万年前後までは夕 ア亜型の割合が減少し，かわってササ亜型の割合が増大 するササ属の優勢なイネ科植生が成立していたと思われ る.関東地域と異なる点は, アカホヤ $(\mathrm{K}-\mathrm{Ah})$ 上部の 腐植層で照葉樹林起源理酸体の出現頻度が高いことと, キビ型がタケ型をうわまわっていることである.このこ とは，暖地型イネ科植物で祭るキビ亜科 ( $\mathbf{C} 4$ 植物)が優勢 であったことを示し，照葉樹林が最る隆盛した時代とも 一致する、尔た，九州の一部の地域では 1 万年前に和い ても照葉樹林の存在徵㩔がイスノキ，ダブノキ，スダジ イに由来する理酸体から示唆された（近藤，1982a，b)． 近藤（1982a）は，各地の累積黒ボク土を用いて, 約 2 万年以後の植生変化を 表-4 のよう纆めている. 分析 された試料は年代が汪涪確定した層準を対象としている が，前述の植物珪酸体分析の結果と矛盾するるのではな い.

以上，通覽してきたように，累積テフラ層の植物珪酸 体分析は連続したイネ科植生，照葉樹林の広がりなど， 自然環境の変遷をたどるうえで極めて有効な方法といえ よう.

な捄，米国火和いて古環境復元のための植物珪酸体研 究は，1960１970 年にわかり，土壤学者によって行わ れてきたが，最近では考古学発掘プロジェクトの一貫々 して研究されることが多い(Pearsall, 1982)。例岇ば， Lewis $(1978,1981)$ は, 北西ネブラスカ州, ワイオミ ング州拉よび北東コロラド州の遺跡土壇を分析し, キビ 型，ヒダシバ型およびウシノケグサ型珪酸体の出現割合 から古植生を復元した．同様な研究は，ROBINSON (1980) によって, テキサス州の中央, 南部和よび沿岸地帯の古 環境を復元する手段として考古学遺跡汇適用された。 
表 4 地域別, 時代別に復元した腐植給源植生 (近藤，1984 a )

\begin{tabular}{|c|c|c|}
\hline 地 & 域 & 腐 植 給 源 植 生 \\
\hline 北海 & 东道 & 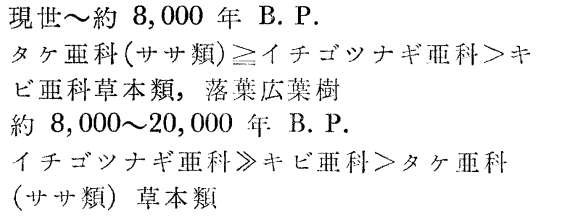 \\
\hline 東 & 北 & 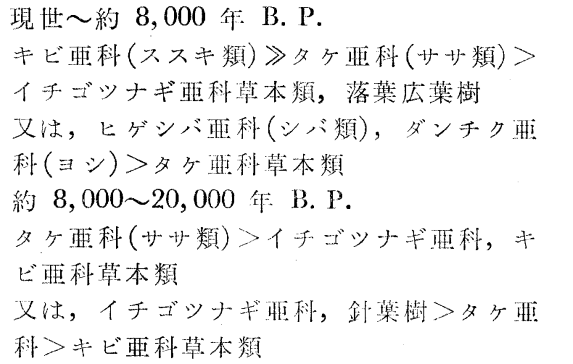 \\
\hline 中 & 部 & 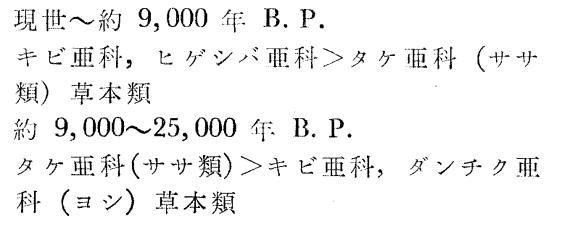 \\
\hline 関 & 東 & 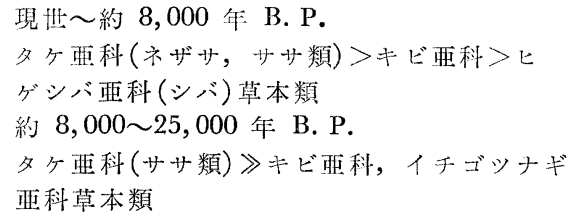 \\
\hline 中 & 国 & 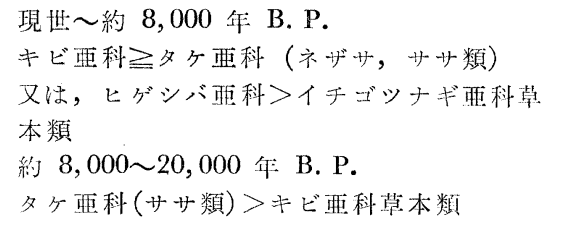 \\
\hline 九 & 州 & 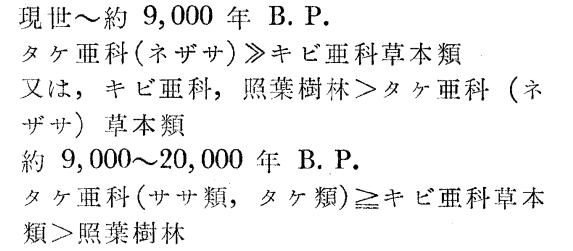 \\
\hline
\end{tabular}

\section{6) 土壤中の年間植物珪酸体生産量および植物乾物量 の概算}

土塞中の植物珪酸体年間生産量(Pwy) は, 試料の層 厚 $(\mathrm{d})$, 仮比重 $(\delta)$, 植物珪酸体含有量 $(\mathrm{w})$ 际よび地 表露出期間（y）のデータから, 前述の式（1）(加藤, 1977) によって求められる: $\mathrm{P}_{\mathrm{wy}}=\mathrm{P}_{\mathrm{w} / \mathrm{y}}$

黒ボク土の年間植物珪酸体生産量は, かなり地域差が
認められ（佐瀬・近藤, 1974 ; 佐瀬 ·加藤, 1976b), 気 温が高くタケ覀型珪酸体を多く含む九州, 宮崎県では最 䯩值 $\left(10 \mathrm{~g} / \mathrm{m}^{2} \cdot \mathrm{y}\right)$ を示し，東北，青秝県では最小 $(0.54$ $\left.\mathrm{g} / \mathrm{m}^{2} \cdot \mathrm{y}\right)$ ，北海道南部では $2.4 \mathrm{~g} / \mathrm{m}^{2} \cdot \mathrm{y}$ とふたたび高く なる。これは, 主要草地型が東北ではスス手, 北海道で はササ類であることと関係している可能性がある(佐瀬・ 加藤, $1976 \mathrm{~b}$; 加藤, 1977).

いずれにしても，土壤中の年平均植物珪酸体生産量 は，代表的イネ科草本（ススキ, $3.3 \mathrm{~g} / \mathrm{m}^{2} \cdot \mathrm{y}$; ササ属, $5.6 \sim 7.4 \mathrm{~g} / \mathrm{m}^{2} \cdot \mathrm{y}$; ネザサ, $15 \mathrm{~g} / \mathrm{m}^{2} \cdot \mathrm{y}$, 佐瀬・加滕, 1976b) 飞比べ全般的に低い。これは，珪酸体をあまり 残さない植物を混じえていることと，小型珠酸体の溶解 が関係していると考觉られている（佐瀬・加藤，1976b ; 加藤, 1977) .

土壤中の植物珪酸体含有量 ( $\mathrm{Pw}$ ) を植物体の珪酸体 含有率 $(\mathrm{S})$ で除すと, 過去の年間乾物量 $(\mathrm{G})$ が推定 できる: $\mathrm{G}=(\mathrm{Pw} \times 100) / \mathrm{S}$

この時, $\mathrm{S}$ は植物種によって異なるので，植物珠酸体 組成から給源種を推定し, 適当な $\mathrm{S}$ を決わる必要があ る.また，別に土壤执よび植物体の特定の珪酸体の個数 を直接法，あるいはグラス・ビーズ法で数え，年間乾物 生産量を推定する方法がある.

藤原 (1979) は福同県・板付および群馬県・日高遺跡 土壤において，また，伀々木(1979)は東京・なすな原お よび三重・北堀遺跡土塨において，それぞれに含まれる 機動細胞珪酸休の密度から，水田として利用された全期 間のイネ, ヨシ,タケ類の乾物生産量を推定した. 近藤・ 石田（1981）は, 北海道・帯広市のカシワ林下に発達す る黒ボク土 $\mathrm{A}_{00}$ および $\mathrm{A}$ 層の植物珄酸体密度から, 力 シワ,ススキミヤコザサの葉部乾物生産量を推定した. カシワは, 風化抵抗性が弱い珪酸体を含有しているた わ，過少評価されたが，ミヤコザサは注浽当な值 $(80$ 〜 $\left.280 \mathrm{~g} / \mathrm{m}^{2} \cdot \mathrm{y}\right)$ を示した.このような単位体積当たりの 珪酸体個数を利用する方法は，農耕地に扣いて過去に施 用されたイネ㩰堆肥量の推定に大いに役立っている。

佐々木・藤原 (1975) は, イネ葉身の機動細胞珪酸体 の形状がイネ族のマコモ，サヤヌカグサ，アシカキと明 確に区別されることに着目し，その機動細胞珪酸体の密 度を測定することによって，過去に施用されたイネ橖堆 肥量を推定した。この結果は, 実際, 施用された 40 年 間の投入量に近似する值 $(39.4 \mathrm{t})$ であった。橋川ほか (1980) は古代から近世むでに開田された滋賀県南部平 地の水田について, 投入されてきたイネ㩰和よびイネ科 植物体の総量を佐々木・藤原 (1975) と同様な方法で検 
討し, 開田以来, 平均 $400 \mathrm{~g} / 10 \mathrm{a} \cdot$ 年以上のイネ菜堆肥 が投入されたことを明らかにした。

土壤中の植物拄酸体量 (Pw) がわかれば, それらの值 を植物体の年間珪酸体生産量 ( $\mathrm{Pw}^{\prime}$ ) で除すことで珪酸 体の蓄積年数 $(\mathrm{Tw})$ が算出される: $\mathrm{Tw}=\mathrm{P}_{\mathrm{w}} / \mathrm{P}_{\mathrm{w}}$

加藤 (1977) は, 東京西部, 赤城南棍, 宇都宮東郊特 よび愛鷹南麓の黑ボク層, ローム層の蓄積年数を求め, それらの結果と既知の考古学的遗物和よび ${ }^{14} \mathrm{C}$ 年代と

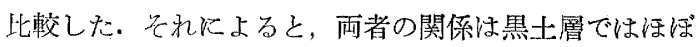
一致するが，ローム層では著しく小さく，四地の黑土層 で洼かなりさい值を示した。このような違いは, 植物 の年間珠酸体生産量を過大, あるいは過小に見積むられ たためと考えられ，試料の堆積環境などを熟知する必要 性が指摘された。

\section{7）野性動物の摄食量および食性の推定}

野生動物の摂食量和よび食性を知る手がかりとして, 最近, 稙物珪酸体分析が注目されている.

従来, 野生動物の瓷拉よび胃の内容物の構成は, そ和 らの中に含要れている植物片をポイント・クォドラード 法(STEWART，1967) を用いて定量的に調べられている.

TAKATSUKI (1978) は，上記の方法に基づいて二ホン

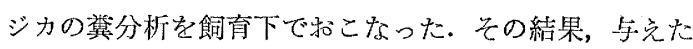
稙物（ススキ，アズマネザサ，シバ）の同定虫可能であ ったが，䬱と冀の量的関係は一致しなかった。

佐藤（1981）は，エゾシカの食性を究明するにあたっ て, 李ず給䭒䒠験から植物珪酸体回収率（採食後，2日 以内に理酸体を排泄) を検討した．慨は，クマイザサ和 よびチモシーを用い，植物体と翼の植物理酸体がそれぞ れ測定され，クマイザサは $97.2 \pm 1.12 \%$ ，チモシーは $94.3 \pm 0.63 \%(99 \%$ 信頼区間) それどれ回收された. このことは，ェジシカの体内で植物珪酸体は注とんど分 解されず，消化にたいして抵抗性があることを示すばか りでなく, 冀中の植物珪酸体分析によって野生動物の抆 食量拉よび食性が定性的，から定量的に把握できること を示唆している。

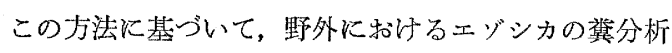
が季節的に追跡された（藤巻泀か，1983）。それにる と, エゾシカは春季に他の時期よりミヤコザサを多く食 べ，それ以降はミヤュザサ以外の草本類を多く採食する ことが推測された。さらに，エゾシカの一日当たりの排 泄量, 掑食した植物種就よびその部位が判明できるなら ば，掑食量の推算も可能である。季た，䨢中の植物珠酸 体組成を調べることで，初和よとの食性が推定でき，野 生動物を保護・管理するうえで貴重な情報を提供するで
あるう。

\section{8）その他の応用}

植物珠酸体の風化度は, 植物珪酸体の性質和よび埋積 環境汇よって変わるが，下層亦るいは埋没年代の古いほ ぞ, 矢の表面に円孔が多数みられ，徐々に輪郭が不明瞭 になる．この珠酸体の風化度に着目し, 加藤(1977)は, 愛鷹山麓の 累積黑ボク土断面の植物珪酸体の風化度と ${ }^{14} \mathrm{C}$ 年代との関係を検討した。 その結果，それらの間に はかなり良い正の相関関係があることをつきとめた。亦

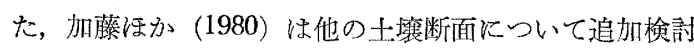
し，前記と同様な結果を得た。河室（1983b）住，加藤 (1977) 之同様な観点から植物理酸体の風化度を4段階 に区分し，そるを入甲田山の火山灰由来の各種土壤（褐 色森林土, ポドソル, 黑色土, 理没黑色土）から分離し た植物珪酸体に適用した．その結果， ${ }^{14} \mathrm{C}$ 年代が古い汪 ぞ, 植物珪酸体の風化度が大きくなるが, 上壤の種類に よって風化度にかなりの違いがあることを認めた。これ らの方法は, ぞの種の藉酸体を対象にするか, 風化度特 よび埋積環境をどのように評価するかなど，煩雑な問題 を抱えている。この点を十分考慮し, 客観的に風化度を 評価できれば，概略の年代判定として適用できよう。

土壤中の植物珠酸体の絶対年代は, 珠酸体侸有され る炭素の ${ }^{14} \mathrm{C}$ 年代測定によって求められる。植物珠酸 体の炭素は，そ机らを給源した植物の繁茂時に珠素と一 緒に吸藏したものであるので，後世の有機物混入の心配 は汪とんと゚ないと思われる。 WILDING (1967) は，才八 イオ州西部のブルニゼム土壤から植物理酸体を分離し， その ${ }^{14} \mathrm{G}$ 年代を測定して, 約 13,300 年という值を得た. ただし，珪酸体の炭素量 $(<0.13 \sim 6 \%)$ はごく僅かし か含有されていないので ${ }^{14} \mathrm{C}$ 年代測定には数キログラム の土裹が必要となる。最近, 炭素量数ミリグラムで ${ }^{14} \mathrm{G}$ 年代測定可能な加速器質量分析器が開発され, 実用化さ れている.この方法が日常的に利用できるなら，植物珠

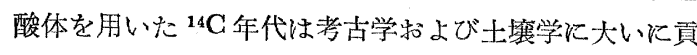
献するであるう。

犯罪事件には，なんらかの形でその現場に衣類，履物 なぞの遗留品が残される。警察は，それらに付着してい

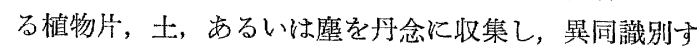
ることで物証の一部として法廷に提示する.このような 犯罪捜査に植物珪酸体が利用された例として放火事件が あり，現場に残された灰の植物珪酸体分析によってイネ 菬が放火に用いられたことが実証された(丸茂, 未発表)。 最近, MARUMo (1986) は, 埼玉県川越市に拈いて地 形，土地利用の異なる土堙の植物珪酸体分析を行い，そ 
れらの違いによって理酸体組成に相異があることを認め た. その結果, 植物珪酸体分析は, 鉱物学的に差の認め られない土壤試料の異同判別を行ら場合，植生の相違が あれば互いに識別できるので，その鑑定に有効な一手法 であると考えた。

最近，この種の研究が都道府県警察の科学捜査研究所 に执いて関心を集めている。

以上，環境復元法としての植物珪酸体の能力について 基礎的な側面とその応用面から紹介してきた。前述して さたように，何の変哲もない一枚の植物葉に隠されてい る自然界の小さな事実が，過去から現在に屯たがる自然 環境とそれをとりまく人間の生活文化の屝を開く鍵とな ってくれることは大変興味深いことである. 今後，わが 国に和いて益々この種の研究が飛躍することを願ってや まない.

\section{9. おわりに}

過去 140 年間, 内外に括いて植物珪酸体に柰つわる 様々な研究が報告されてきたが，その数は 300 篇を越 えていない，その多くは1958 年以降からの研究であ り，同時代に研究の緒についた花粉分析研究に比べる と，かなり見劣りがする。

最近，10 年間のわが国和よび米国に和ける植物珪酸 体研究の発展は目を見張るものがある，とくに，わが国 に和将る黒ボク土腐植層の給源植物の同定，水稲栽培の 歴史, 草地植生の変遷, 照葉樹林起源珪酸体の同定, 米 国に括けるトウモロコシ栽培の歴史，作付体系の変遷， 古環境の復元などの研究例があげられよう。

これまで述べてきたよらに，植物珪酸体分析はある面 に沶いて花粉分析に匹敵する環境復元法といえるが，研 究を着手してから日があだ浅く，発展段階にあるため方 法論などに执いても未解決の問題が多い。しかし，その 応用範囲が広く，各分野にわたって成果が期待できるた め,さらに，一層の基礎研究が望まれる。

今後, 究めるべき若干の項目を以下に列記し, 結とす る.

(1). 体系的植物珪酸体分類の確立（とくに，イネ科は 属レベルまで細分), (2). 各種植物の珪酸体生産量（量, 個数）リストの作製，(3)、各種環境下に和兴珪酸体の 物理, 化学的動向 (移動性, 安定性), (4). 植物珪酸体組 成と現植生との対応関係，(5). イネ以外の栽培植物の歴 史および作付体系の変遷， (6).同一試料に括ける植物珪 酸体と大型植物遺体，花粉・胞子などとの相互関係を検 討あるいは解明する必要があるう。

\section{交献}

Alexander, J. D., J. B. Fehrenbacher, and B. W. RAY(1968) Characteristics of dark colored soils developed under prairie in a toposequence in northwestern Illinois. p. $34-38$, In P. SGhramm(ed.), Prairie and prairie recostruction. Knox College Biol. Field Sta. Spec. Pub. 3, Galesburg, Fllineis

AnderJweko, M. J. (1983) Biogenic silica in peats: possible source for chertification in lignites. Los Alamos Natl. Lab.(Rep.) La(U.S), La-9907-OBES, Miner. Matter Peat, DE84-002332, p. 25-37, Chemical Abst., 101, $9402 \mathrm{~V}$

Anderson, D. W. (1979) The pedologenetic origins and characteristics of organic matter of solod soils. Can. J. Soil Sci., 59, p. 357-362

Amos, G. L. (1952) Silica in timbers. Comm. Sci. Ind. Res. Org. Aust. Bull., 267, p. 1--55

有村玄洋. 管野一朗 (1965a) 植物蛋白石飞ついて（子 報)．九州農試彙報，11，p. 97-109

Arimura, S. and Kanno, I. (1965b) Some mineralogical and chemical characteristics of plant opal in soils and grasses of Japan. Bull. Kyushu Agric. Expt. Sta., 11, p. $110-120$

Armitage, P. L. (1975) The extraction and identification of opal phytoliths from the teeth of ungulates. Jour. of Archaeol. Sci., 2, p. 187-197

BABA, I. (1956) Studies on the nutrition of the rice plant with special reference to nitrogen and silica. Proc. Roy. Soc. Japan, 24, p. 29-33

BArker, G. (1959a) Fossil opal-phytoliths and phytolith nomenclature. Aust. J. Sci., 21, p. 305-306

BArker, G. (1959b) Opal phytoliths in some Victorian soils and "red rain" residues. Aust. J. Bot., 7, p. $64-87$

Barker, G. (1960a) Phytolitharien. Aust. J. of Sci., 22, p. $392-393$

Barker, G. (1960b) Hock-shaped opal phytoliths in the epidermal cells of oats. Aust. J. Bot., 8, p. 69-74

Barker, G. (1960c) Fossil opal phytoliths. Miropaleontology, 6, p. 79-85

BARker, G. (1960d) Phytoliths in some Australian dusts. Proc. Roy. Soc. Victoria., 72, p. 21-40

Bartoli, F. (1985) Crystallochemistory and surface properties of biogenic opal. J. Soil Sci., 36, p. 335350

Bartoli, F. and Selmi, M. (1977) Sur l'evolution du silicium végétal en milieux pédogénétiques aérés acides. C. R. Acad. Sci. Paris Series D 284, p. 279-282

Bartoli, F. and B. Souenier (1978) Cycle et rôle du silicum d'origine végétale dans les écosystèmes forestiers tempérés. Ann. Sci. Forest, 35 p. 187-202 Bartol., F., L. J. Monrozier, and J. L. Rapaire(1980) Sur la stabilisation des matières organiques azotées 
par les minéraux silico-alumineux dans les podozols: phytolithes et argiles. C. R. Acad. Sci., Paris Series D 291, p. $183-186$

Bartoli, F., and L. P. Wilding (1980) Dissolution of biogenic opal as a function of its physical and chemical properties. Soil Sci. Soc. Am. J., 44, p. 873-878

Beavers, A. H. and I. Stephen (1958) Some features of the distribution of plant opal in Illinois soils. Soil Sci., 86, p. $1-5$

Blackman, E. (1968) The pattern and sequence of opaline silica deposition in rye (Secale cercale L.) Ann. Bot., 32, p. 207-218

Blackman, E (1969) Obscrvations on the development of the silica cells of the leaf sheath of wheat (Triticum aestivum). Can. J. Bot., 47, p. 827-838

Blackman, E. (1971) Opaline silica bodies in the range grasses of southern Alberta. Can. J. Bot, 49, p. $769-781$

Blackman, E. and D. W. Parry (1968) Opaline silica deposition in rye (Secale cereales L.). Ann. Bot., 32, p. $199-206$

Bonnet, O. T. (1972) Silicification cells of grasses: a major source of plant opal in Illinois soils. Agr. Exp. Sta. Bull., 742, p. 1-32

Brown, D. A. (1984) Prospects and limits of a phytolith key for grasses in the central United States. J. Archaeol. Sci., 11, p. 345-368

Brydon, J. E., W. G. Dore, J. S. Clark (1963) Silicified plant asterosclereids preserved in soil. Soil Sci. Soc. Am. Proc., 27, p. 476-477

Carlquist, S. (1961) Comparative plant anatomy. 146p., Holt, Rinehart\&Winston, New York

Campos, A. G. and L. G. Labouriau (1969) Corpos silicosos de gramineas dos Cerrados II. Pesq. agropec. bras. 4, p. $143-151$

Cutler, D. F. (1978) Applied plant anatomy. 103 p., Longman, London, 入門志用植物解剖学（遠山益訳， 1981)，210p.，共立出版，東京

Drum, R. W. (1968) Silicification of Betula woody tissue in vitero. Science. 161, p. 175-176

Edman, G. and E. Söderberg (1929) Auffindung von Rcis in einer Tonscherbe aus einer etwas Füntausendjähringen chinesischem Siedlung. Geol. Soc. China, 8, p. 363-365

Ehrenberg, G. G. (1838) Beobachatungen über neue Larger fossiler Infusorien und des Vorkommen von Fichtenblütenstaub neben deutlichen Fichtenholz, Haifischzähnen, Echintten und Infusorien in volhynischen Feuersteinen der Kreide. Ver. Preuss. Akad. Wiss. Berlin

Ehrenberg, G. G. (1847) Passatstaub und Blutregen. Deutsche Akad. Wiss. Berlin Abh., 1847, p. 269-460

EhrenberG, G. G. (1854) Microgeogic, das Erde und Felsen shaffende Wirken des unsichtbar kleinen selbstangingen Lebens auf der Erde. 374p., L. Voss, Leipzig

Figueiredo, R. C. L. and W. Handro (1971) Corpos silicosos de gramineas dos Cerrados V. p. 215-230, III Simposio sobre o Cerrado, Edqard Blucher, Saõ Paulo

藤巻祐蔵, 立原厚子, 佐藤孝則 (1985) 植物理酸体に上 るエゾシカの食性分析, 日生熊講演要旨集, 32, p. 97

Folger, D. W., L. H. Burakte and B. C. Heezen (1967) Opal phytoliths in a North Atlantic dust fall. Science, 155, p. 1243-1244

藤原宏志 (1974) 野方中原遺跡土壤の Plant Opal 分析, 福岡市埋藏文化財調查報告畫，30， p. 50-51

藤原宏志 (1676a) 板付遺跡に括沙る Plant Opal 分析, 福阔市埋藏文化財調查報告畫，35， p. 53-58

藤原宏志 $(1976 \mathrm{~b})$ プラント・オパール分析法の基礎的 研究 (1) 一数種イネ科植物の珪酸体標本亡定量分析法 一，考古学之自然科学，9， p. 15-29

藤原宏志 $(1976 \mathrm{c})$ プラント・カパール分析による古代 栽培植物遺物の探索, 考古学雑誌, 62, p. 54-62.

藤原宏志 $(1976 \mathrm{~d})$ 古代土器胎土に含まれるプラント・ オパールの検出, 考古学ジャーナル, 125, p. 6-10

藤原宏志（1979）プラント・オパール分析法の基礎的研 究 (3)一福岡 ·板付遺跡（夜曰期）水田括よび群馬 · 日高遺跡（弥生時代）水田に拈々るイネ(O. sativa L.) 生産総量の推定一，考古学と自然科学，12, p. 2942.

藤原宏志 (1980) プラント・オパール分析の基礎的研究 (4)一熊本地方比打る䋥文士器胎土に含まれるプラ ント・オパールの檢出一考古学と自然科学, 13, p. 55 $-65$.

藤原宏志 (1983) プラント・オパールからみた縄文から 弥生一縄文晚期から弥生初頭に持ける稲作の実証的検 討一，歴史公諭， 8, p. $63-70$

藤原宏志 (1984) プラント・オパール分析法とその応用 一先史時代の水田址探查一，考古学ジャ一ナル，227, p. $2-7$

藤原宏志・佐々樟 (1978) プラント・ォパール分析法 の基礎的研究 (2)一イネ(Oryza) 属植物に括ける機動 細胞珪酸体の形状一，考古学と自然科学，11， p. 920

藤原宏志・佐从木章・末吉孝行 (1975) 熊本・上ノ原遺 跡 (縄文晚期初頭) 土壤の Plant Opal 分析, 日本作 物学会九州支部会報, No. 42, p. 49-53

Gers, J. W. (1973) Biogenic silica in selected species of deciduous angiosperms. Soil Sci., 116, p. 113130

GeIs, J. W. and R. L. Jones (1973) Ecological significance of biogenic opaline silica. p. 74-85, In D. L. Dinal (ed.), First soil microcommunities Conf. USAEC, Soil Microcommunities $I$.

GiLl, E. D. (1967) Stability of biogenetic opal. Science, 158, p. 810

Grob, A. (1896) Beitrage zur Anatomie der Epidermis der Gramineeblatter. Bibliotheca Botanica 7, p. 1-122 
HANDREGK, K. A. and L. P. H. Jones (1967) Uptake of monosilicic acid by Trifoium incarnatum (L.). Australian J. Biol. Sci, 20 p. 483-485.

橋川 潮 - 森脇 勉 - 渡部忠世 (1980) 水田に投入され た有機物の定量一古代から近世までに開田された水田 の諸例，日作紀，49，別号 2，p. 153-154.

早田文藏 (1929) ササ属の解剖分類学的研究, 植物学雑 誌，43，p. 23-45

Helbaek, H. (1952) Early crops in southern England. Proc. Prehist. Soc. 18, p. 194-233

Herbaek, H. (1959) How farming began in the Old World. Archaeology, 12, p. 183-189

Helbaek, H. (1961) Studing the diet of ancient man. Archaeology, 14, p. 95-101

平田友信・佐伯 浩・原田 浩 (1972) 南洋材の柔細胞 中の結晶およびシリカの走查電子顕微鏡による観祭， 京大農学部演習林報告, No. 44, p. 194-205.

平川一臣 (1975) 東・中部ヨーロッパに和汀最終水期 の細分に関する諸研究の紹介, 第四紀研究, 14, p. $123-138$

細野郝 - 佐瀬 隆 (1985) 浦和市の関東口-ム層一之 くに鈗物と植物理酸体について一，p. 83-101，浦和 市史「調查報告畫第 17 集自然編」, 埼玉県浦和市総務 部市史編篹室

石田英一郎・泉 靖一編 (1967) シンポジュウム日本農 耕文化の起源，210p.，角川書店，東京

Jones, J. B., J. V. Sanders and E. R. Segnit (1964) Structure of opal, Nature, 204, p. 990-991.

Jones J. B. and E. R, Segnit, (1971)The nature of opal. I. Nomenclature and constituent phases. $J$. Geol. Soc. Aust., 18, p. 57-68.

Jones, L. H. P. and K. A. Handreck (1963) Effects of iron and aluminum oxides on silica in solution in soils. Nature, 198, p. 852-853.

Jones, L. H. P. and K. A. HANdREGK (1967) Silica in soils, plants, and animals. Adv. Agron., 19, p. $107-149$.

Jones, L. H. P. and A. A. Milne (1963) Studies of silica in the oat plant. I. Chemical and physical properties of the silica. Plant Soil, 18, p. 207220.

Jones, L. H. P., A. A. Milne, and J. V. SAnders (1966) Tabashir: an opal of plant origin. Science, 151, p. $464-466$.

Jones, R. L. (1964) Note on occurrence of opal phytoliths in some Cenozoic sedimentary rocks $J$. Paleontol., 38, p. 773-775.

Jones, R. L. and A. H. Beavers (1963) Some mineralogical and chemical properties of plant opal. Soil Sci., 96, p. 375-379.

Jones, R. L. and A. H. Beavers (1964a) Aspects of catenary and depth distribution of opal phytoliths in Illinois soils. Soil Sci. Soc. Am. Proc., 28, p. 413416.

Jones, R. L. and A. H. Beavers (1964b) Variation of opal phytolith content among some great soil groups in Illinois. Soil Sci. Soc. Am. Proc., 28, p. $711-712$.

Jones, R. L. and W. W. HAY (1975) Bioliths. p. 481-496, In J. E. Giesking (ed.), Soil Components, Vol. 2, Inorganic components, SpringerVerlag, New York.

Jones, R. L., W. W. Hay, and A. H. Beavers (1963) Microfossils in Wisconsin loess and till from western Illinois and eastern Iowa. Science. 140, p. 12221224.

Jones, R. L., J. MaKenzie, and A. H. BeAvers (1964) Opaline microfossils in some Michigan soils. Ohio J. Sci., 64, p. 417-423.

Johnston, A., L. M. Bezeau and S. Smoliak (1967) Variation in silica content of range grasses. Can. J. Plant Sci., 47, p. 65-71.

上條朝宏 (1984) 縄文土器の胎土分析, 歷史公論, 10, p. $134-147$

捾野一郎（1961）日本の主要土壤型の生成分類学的研究 $\mathrm{I}$, 序論および第 1 編 腐植質アロフェン士，九州農 試鲁報，7，p. 1-185

管野一郎・有村玄洋 (1958a) 土境中の植物盆白石 (Plant Opal) について, ペドロジスト， 2, p. 78-85

Kanno, I. and S. Arimura (1958b) Plant opal in Japanese soils. Soil Plant Food, 4, p. 62-76.

加藤富司 (1932) 本邦産大麦の「スポドグラム」, 宮崎高 等農林学校学術報告, 4 号, p. 87-110

加藤富司 (1933) 小麦の葉の「スポドグラム」, 宮崎高等 農林学校学術報告, 5 号, p. 29-50

加藤芳朗 (1958)「黒ボク」土㙵中のプラント・オパール について，ペドロジスト， 2, p. 73-77

加藤等朗 (1960)「黑ボク」土壤中の植物起源粒子につい て (予報)，土肥誌，30， p. 549-552

加藤芳朗 (1962) 関東口一么層の細砂鉱物組成, 地球科 学, 62, p. 11-20

加藤芳朗 (1963) 火山圧中の植物球酸体, 第四紀研究, 3, p. $59-61$

加藤芳朗 (1975) 元野遗跡発掘調查報告青, p. 48-49, 沼津市教育委員会

加藤芳朗 (1977) 植物珪酸体一土の化石一, 静岡地学 36 号, p. 4-16

加藤芳朗 (1933) 火山灰土の生成メカニズム, p. 5-30, 火山灰上一生成・性質・分類一, 日本土壇肥料学会編, 博友社:

加藤芳朗・佐瀨 隆 - 堺井茂雄 - 金沢信夫 (1980) 植物 理酸体による土壤生成年代の推定，士肥要旨集， $\mathbf{3 0}$, p. 133

Kaufman, P. B., W. S. Bigelow, R. Schmid, and N. S. GHosher (1971) Electron microprobe analysis of silica in epidermal cells of Equisetum. Amer. J. Bot., 58, p. 309-316.

河室公康 (1981) 火山抛出物に由来する森林土埪の生成 学論的研究 (III) 一長野県黒姫山の褐色森林土之黑色土 について (予報)一，92回日林論，p．183-186 
河室公康（1983a）十和田火山圧由来の褐色森林土括上 び黒色土のA層拉よび埋没 $\mathrm{A}$ 層中の植物珪酸体につい て，94回日林諭，p. 183-186

河室公康 $(1983 \mathrm{~b})$ 土壤中の植物珠酸体の風化度と年代 との関係について，35回日林関東支論，p．123-126

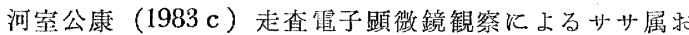
よびススキ属等の植物珪酸体の形態について，35回日 林関東支諭，p. 127-129

河室公康 (1984) 植物珪酸体 (I) 一林野に群生する主な イネ科植物葉中の植物珪酸体の形態, 森林立地, 26, p. $18-25$

Krein, R. L. and J. W. GeIs (1978) Biogenic silica in the Pinaceae. Soil Sci., 126, p. 145-156.

近藤錬三 (1974) Opal phytoliths一植物珪酸体の形態的 特徵とイネ科植物分類グループとの関連一，ペドロジ スト, 18, p. $1-10$

近藤銝三 (1975) 樹木起源の理酸体について，ペドロジ スト, 20, p. $174-190$

Kondo, R. (1977) Opal phytolith, inorganic particles in plants and soils. JARQ, 11, p. 198--203.

近藤鍊三（1980）泥炭土の有機物汇関与る化学的研省， 376 p., 博士論文, 名古屋大学

近藤鍊三 (1981) 弁天橋遺跡土壤の植物珠酸体分析, p. 67-71, 弁天橋遺跡調查報告書，八王子市弁天橋遺跡 調查研究会

近藤錬三 (1982a) Plant Opal 飞よる黑色腐植壃の成因 究明に関与る研究, 32 p., 昭和 56 年度科学研究費 (一 般研究 $\mathbf{G}$ ) 研究成果報告書

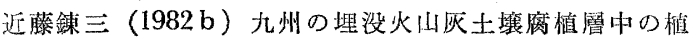
物珪酸体について，土肥要旨集，28，p．146

近藤鍊三(1982 c ) 茅野求御社宮司遺跡土壤のプラント・ オパール分析， p. 208-212，長野県中央道埋蔵文化 財包蔵地発掘調查報告一茅野市その5-昭和 $52 \cdot 53$ 年度, 日本道路公団名古屋建設局・長野県教育委員会 近藤鎪三 (1983a) 植物珪酸体（プラント・オパール） 分析の農学特よび理学への応用, 十腾農学談話会誌, 第 24 昂，p. $66-83$

近藤錬三 $(1983 \mathrm{~b})$ 土壤中の植物起源オパール“植物珪 酸体分析”から何がわかるか，化学と生物，21，p. $739-741$.

近藤錬三 $(1984 \mathrm{a})$ プラント・オパールとその応用をめ ぐって，歴史公碖，10, p. 114-123

近滕銤三 $(1984 \mathrm{~b})$ 土堆中の非イネ科起源珪酸体につい $\tau$, 土肥要旨集, 30, p. 149

近藤錬三 (1985) 扂辺 16 遗跡土裴の植物珪酸体分析, p. 70-77，居迅遗跡，上士幌町教育委員会

近藤鍊三・原田孝幸 (1980) 泥炭地植物括よび泥炭土の 植物ケイ酸体について，土肥要旨集，26，p. 134

近藤鉬三・石田正人 (1981) カシワ林下の火山灰土壤の 植物珠酸体飞ついて，土肥要旨集，27，p. 125

Kondo, R. and Y. IwASA (1981) Biogenic opal of humic yellow latosol and yellow latosol in Amazon region. Res. Bull. Obihiro Univ., 12, p. 231-239. 近藤錬三・小崎 隆 (1986) 西アフリカ低地土㙵植物 珪酸体について，土肥要旨集，32，p.134
近藤錬三・太田泰広 (1979) 水分咊境党異にする火山灰 土壤腐植層中の植物珪酸体飞ついて, 土肥要旨集, 25, p.233

近藤鍊三・ピアスン友子（1981）樹木葉の方イ酸体に関

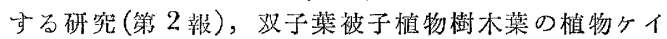
酸体について，带畗大研報，12，p. 217-229

近藤錬三・栄美津子（1979）ササ類の理酸体について， 土肥要旨集，25, p. 148

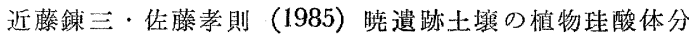
析, 土器胎土の植物珪酸体組成, p. 121-132, 帯公 市埋蔵文化財調查報告畫「带広・垷遺跡」，带広市教 育委員会

近藤鍊三・隅田友子（1978）樹木葉の片酸体に関する 研究(第 1 埌)，裸子植物括よび単子葉被子植物樹木葉 の植物ケイ酸体について，土肥誌，49，p. 138-144. 近藤鏳三・佐瀨隆・相馬 靖 (1983) イネ科草本類起 源ケイ酸体の細分類について, 土肥要旨集, 29, p. 143 近藤良男 (1931) 欧像飞よる生薬鑑識の研究，第 3 派， 薬学雑誌，51，p. 913-935

Kurmann, M. H. (1982) An opal phytolith and palynomorph study of extant and fossil soils in Kansas. Ohio J. Sci., 82, p. 18.

LANNIng, F. C. (1961) Silica and calcium in black raspberries. Proc. Amer. Hort. Soci., 76, p. 349358.

Lanning, F. C., W. X. Ponnaiya, and C. F. CRumPTON (1958) The chemical nature of silica in plants. Plant Physio., 33, p. 339-343.

Lathrap, D. W., J. G. Margos, and J. A. Zeidlek (1977) Real Alto: An ancient ceremonial center. Archaeology, 30, p. 2-13.

Lewis, R. O. (1978) Use of opal phytoliths in paleoenvironmental reconstruction. Wyoming Contributions to Anthropology. 1. p. 127-132, Cited from D. M. Pearsall (1982).

Lewis, R. O. (1981) Use of opal phytoliths in paleoenvironmental reconstruction. J. Ethnobiol. 1, p. $175-181$.

LuTwiak, L. E. (1969) Identification of phytoliths in soils. p. 77-82, In S. PAwluk (ed.), Pedology and Quarernary Research Symposium, National Canadian Research Council and Univ. of Alberta, Canada.

町田洋・鈴木正男 (1971) 火山灰の絶対年代と第四紀 後期の編年一フィッション・トラック法による試み, 科学, 41, p. $263-270$

松井，健・成瀨洋・黑部 隆 (1968) 垃川口-么層中 の暗色带 (埋没古土境腐植層) の ${ }^{14} \mathrm{G}$ 年代，地球科学， 22, p. $40-41$

Marumo, Y. (1986) Morphological analysis of opal phytoliths for soil discrimination in forensic science investigation. Jour. of Forensic Scienes, Manuscript. 松谷暁子（1981 a ）長野県諏訪原村大石遺跡で出土の夕 一ル状炭化粒子の同定について，p．141-143，長野 県中央道埋藏文化財発掘調查報告一諏訪市乞の4一炤 和 54 年度鑑定結果 
松谷暲子 $(1981$ b $)$ 兏像と岸化像による縄文時代の作物 栽培の探究, 考古学ジャーナル，192, p. 20-22

Mehra, P. N. and O. P. Sharma (1965) Epidermal silica cells in the Cyperaceae. Botan. Gaz., 126, p. 53 58.

Metcalfe, C. R. (1956) Some thoughts on the structure of Bamboo leaves. Bot. Mag. (Tokyo), 69, p. $391-400$.

Metcalfe, C. R. (1960) Anatomy of the Dicotyledons. I. Gramincae. 731 p., Oxford Univ. Press, London.

Mikkelson N. (1984) Diatoms in the Zaire deep sea-fan and Pleistocene paleoclimatic trends in the Angola basin and west Equatorial Africa. Neth. J. Sea Rers. 17, p. 280-292, Biological Abst., 79, 70260.

Miller, A. (1980) Phytoliths as indicators of farming techniques. Paper presented at the 45th meeting of society for American Archaeology, Philaderphia, Cited from D. M. Pearsali (1982).

Moligh, H. (1920) Aschenbild und Pflanzenverwandschaft. Stizb. Akad. Wiss. Wien, 129, p. 261294.

中村 純 (1967) 花粉分析, 232p., 古今書院, 東宁

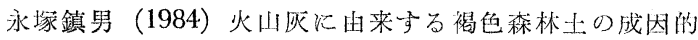
特徽（2）二土壤生成に及活す植生の影響一，土肥要旨 集, 30, p. 148

Nanko, H. and W. A. Côtẽ (1980) Grystals and other inclusions in the phloem, p. 47-51, Bark structure of hardwoods grown on southern pine sites. Syracuse Univ. Press, Syracuse, New York.

南光浩毅 - W. A. CôT $\tilde{\mathrm{E}}$ (1981) Magnolia と Aphananthe の二次師部中のシリカを含さ師部㵶維, 第 31 回日本 木材学会大会研究発表要旨集, p. 70

Netolizky, F. (1929) Die Kieselkörper. p. 1-19, In K. Linsbaure (ed.), Handbuch der Pflanzenanatomie, Berlin.

Norgren, J. A. (1973) Distribution, form and identificance of plant opal in Oregon soils. Ph. D. Dissertation, 176p. Oregon State Univ., Corvallis, Diss. Abst. Int., 33, $4321 \mathrm{~B}$.

Numata, M. (1969) Progressive and retrogressive gradient of grassland vegetation measured by degree of succession-Ecological judgement of grassland and condition and trend IV. Vegetatio, 19, p. 96-127.

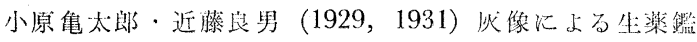
識の研究 (第 $1 \sim 2$ 報), 薬学雑誌, 49, p. 1036 1048, 51, p. $738-749$

Oberholster, R. E. (1968) A method for the separation of plant opal in soils. S. Afr. J. Agric. Sci., 11, p. $195-196$.

大池昭二・松山 力. 竹内貞子 (1977) 八户浮石層直下 の埋没化石林の ${ }^{14} \mathrm{C}$ 年代一日本の第四紀層の ${ }^{14} \mathrm{G}$ 年代 (118) 一, 地球科学, 31, p. 136-137

大木麒一 (1927-30) 竹類のアッシェンビルドの分類学
的洒值飞就きて(予報 1 9), 植物学雑誌, 41, p. 719 $-731,42$, p. $270-278$, p. $311-317$, p. $383-395$, p. $515-524,43$, p. $193-205$, p. $479-489,44$, p. $351-359$, p. $534-545$

大越昌子 (1980) 市川市土宇遺跡 No. 100 地点に打㤝

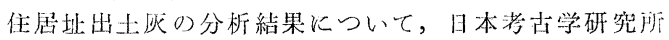
集報，II， p. 90--113

大越昌子 (1982 a ) 能角寺ニュータウン遺跡群, III. 㗪 土中の灰の分析， p. 341-360, 鹃牦寺ニュータウン 遺跡調查会

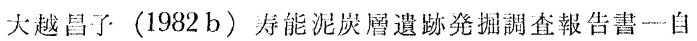
然編一3. プラント・オパール， p. 239-265, 埼玉 県教育委員会

Parfenova, E. I. and E. A. Yarilova (1962) Mineralogical investigation in soil science. 206 p., Acad. of Sci. (USSR), 土壤鉱物学 (佐野 豊訳), 238 p., た たら書房, 米子.

PARry, D. W. and F. Smithson (1958) Silicification of bulliform cells in grasses. Nature, 181, p. $1549-1550$.

Parry, D. W., and F. Smithson (1964) Type of opaline silica deposits in the leaves of British grasses. Ann. Bot., 28, p. 169-185.

Parry, D. W. and F. Smithoson (1966) Opaline silica in the inflorescences of some British grasses and cereals. Ann. Bot., 30, p. 525-538.

Pease, D. S. and J. U. Anderson (1969) Opal phytoliths in Bouteloua Eriopoda Torr. roots and soils. Soil Sci. Soc. Amer. Proc., 33, p. 321-322.

Pearsall, D. M. (1978) Phytolith analysis of archacological soils: Evidence for maize cultivation in formative Equador. Science, 199, p. 177--178.

Pearsall, D. M. (1980) Phytolith evidence of Achira and maize cultivation in formative Ecuador. Paper presented at the 45 th meeting of the Society for Amer. Archaeol., Philadelphia, Cited from D. M. Pearsall (1982).

Pearsall, D. M. (1982) Phytolith analysis: Applications of a new paleoethnobotanical technique in archaeology. Amer. Anthropol., 84, p. 862-871.

Pearsall, D. M. and M. K. Trimble (1984) Identifying past agricultural activity through soil phytolith analysis: a case stuby from the Hawaian Islands. J. Archeaol. Sci., 11, p. 119-134.

Peinemann, N., M. Tschapek, and R. Grassi (1970) Properties of phytoliths. Z. Pflanzenernahr. Bodenkd., 127, p. 126-133.

Piperno, D. R. (1979) Phytolith analysis of archacological soils from central Panama. Master Thesis, Temple Univ., Cited from D. M. Pearsall (1982). Piperno, D. R. (1980) Phytolith evidence for maize cultivation in central Panama during the early ceramic (Monogrillo) period. Paper presented at the 45th meeting of the Society for Amer. Archaeol., Philadelphia, Cited from D. M. Pearsall (1982). 
Piperno, D. R. (1981) First report on the phytolith analysis of the Vegas site OGSE-80, Ecuador. In the Vagas culture: Early prehistory of southwestern Ecuador. K. E. Stothert (ed.) Guayaquil, Ecuadol: Museo Antropologico del Banco Central, Cited from D. M. Pearsall (1982).

Prat, H. (1936) La Systématique des Graminées. Ann. Sci. Nat. Bot. Biol. Ver., 18, p. 165-258.

Prat, H. (1960) Vers une classification naturelle des graminées. Bull. Soc. Bot. France, 107, p. 3279.

Raeside, J. D. (1970) Some New Zealand plant opals. N. Z. J. Sci., 13, p. 122-132.

Retallagk, G. J. (1984) Completeness of the rock and fossil record: some estimates using fossil soils. Paleobiology, 10, p. 59-78.

Richer, H. G. (1980) Occurrence, morphology and taxonomic implications of crystalline and siliceous inclusions in the secondary xylem of Lauraceae and related families. Wood Sci. Technol., 14, p. 35-44.

RrQuiER, J. (1960) Les phytoliths de certain sols Tropicaux et des podzols. Int. Cong. Soil Sci. Trans. 7th (Madison, Wis.), 1960, p. 425-431.

Robinson, R. L. (1980) Environmental chronology for central and south Texas: External correlations to the gulf costal plain and southern high plains. Paper presented at the 45th meeting of the Society of Amer. Archaeol., Philadelphia, Cited from D. M. Pearsall (1982).

Rovner, I. (1971) Potential of opal phytoliths for use in paleoecological reconstruction. Qurt. Res., 1, p. $343-359$.

Rovner, I. (1975) Plant opal phytolith analysis in Midwestern Archaeology. A "new palynology, in prehistic research, Michigan Academian, 7, p.129-137

RuprechT, F. (1866) Geobotanical investigations on chernozem. Acad. Sci. (USSR), Cited from G. Barker (1959).

SANGster, A. G. (1970) Intercellular silica deposition in mature and senescent leaves of Sieglinga decumbens (L.) Bernh. Ann. Bot., 34, p. 557-570.

佐々木章 (1979) 東京・なすな原遺跡拉よび三重・北堀 遺跡（古墳時代·水田）に叔けるイネ生産量の推定, p. 98-101，自然科学の手法による遺跡・古文化財等 の研究, 昭和 53 年度年次報告書

作々木章 (1984) 焼烟山地土壤のプラント・乎ール分 析一宮崎県椎葉村向山一, p. 747-752, 古文化財比 関与る保存科学々人文・自然科学・総括報告書

佐々木章・藤原宏志 (1975) 過去に施用された稻橖堆肥 量を推定する方法, Plant opal 分析の応用, 日本作 紀, 44, 別号 1， p. 65-66

佐瀬隆 $(1980 \mathrm{a})$ 南部浮石層直下の埋没土墒の植物球 酸体分析，第四紀研究，19，p. 119-124

佐瀬 隆 $(1980 \mathrm{~b})$ 八戸浮石層直下の埋没土壤の植物理
酸体（プラント・ホパール）分析，第四紀研究，20, p. $15-20$

佐瀬 隆 $(1980 \mathrm{c})$ 植物珪酸体（プラント・オパール） 分析一古環境復元の新しい方法一，岩手の地学，第 12 号, p. 32-40

佐瀬 隆 (1981) 土器胎土の植物珪酸体分析, p. 145, 縄文土器の胎土分析, 歴史公論, 10, (上條敦宏)

任瀬 隆（1982）古墳時代住居址の炬に関する烧土につ いて，一植物起源糔子の植物珪酸体から見て一， p. 303-308, 多摩ニュータウン遺跡, 東京都埋蔵文化財 センタ一調查報告畫（第 2 集）

作瀨 隆 (1984) No. 122 遗跡の住居址炉跡のプラント オパール分析, p. 140-149, 多摩ニュータウン遗跡, 東京都埋藏文化財センタ一調查報告書

佐瀬 隆 - 細野 衛 - 加藤定男 - 駒村正治 - 倉林三郎 · 宇津川徹 (1982) 成増路露に赫ける関東ローム層の諸 特性, その 2-植物珪酸体分析, 日本第四紀学会講演 要旨集，12, p. 62-63

佐瀬 隆・加藤芳期 (1976a) 現世ならびに埋没火山灭 土壤腐植層中の植物起源粒子---之くに植物珪酸体に関 与る研究 (第 I)，一給源植物の推定に関寸る研究一, 第四紀研究，15，p. 21-34

侮瀬 隆・加藤芳朗 $(1976 \mathrm{~b})$ 現世ならびに埋没火山厕 土壤腐植層中の植物起源粒子一之くに植物理酸体に関 する研究（筈II報）一火山灰士の腐植給源植物飞関与 る問題と植物球酸体を用いた古気候推定一，第四紀研 究， 15, p. 66-74

佐瀬 隆・加藤芳朗・牧野誠一（1985）富士山麓蛙よび 天城山椎の火山网士煹の植物珪酸体分析，ペドロジス 卜，29， p. 44-59

佐瀬 隆 - 近藤鍊三 (1974) 北海道の埋没火山灰土雇植 層中の椎物珄酸体について, 带畜大研報, 8, p. 147 $-183$

佐竹莩輔(1929-30) イラクサ群植物に於ける葉のSpodograms $の$ 分類学価値に就きて, 第 $1 \sim 3$ 報, 植物学 雑誌, 43, p. 206-216, p. 413-421，44, p. 113 120

佐藤孝則 (1981) エゾシ力翼の植物理酸体による食性の 研究, 48p., 修士論支, 寡広畜産大学

Scurfield, G., C. A. Anderson, and E. R. Segnit (1974) Silica in woody stems. Aust. J. Bot., 22, p. $211-229$.

Sendulsky, T. S. and L. G. Labouriau (1966) Corpos silicosos de gramineas dos Cerrado-I, p. 159 170, In L. G. Labouriau (ed.), II. Simpôsio sôbreo Cerrado. Anais Acad. Brasil Ciências, 38, Suplemento.

Smrtuson, F. (1956a) Plant opal in soil. Nature, 178, p. 107.

Smrruson, F. (1956b) Silica particles in some British soils. J. Soil Sci., 7, p. 122-129.

Smrthon, F. (1958) Grass opal in British soils: $J$. Soil Sci., 9, p. 148-154.

Stering, C. (1967) Crystalline silica in plants. Amer. J. Bot., 54, p. 840-844.

Stewart, D. R. M.(1965) The epidermal characters 
of grasses, with special reference to East African plains species. Bot. Jb., 84, p. 63-116, p. $117-$ 174.

Stewart, D. R. M. (1967) Analysis of plant epidermis in faeces: a technique for studying the food preferences of grazing herbivores. J. Appl. Ecol., 4, p. $83-111$.

須藤彰司・飯高和美 - 山根又光・㞸見 優 (1967) 南洋 材中のシリカの存在, 林業試験場研究埌告, No. 200, p. $43-55$

高橋英一・它靖一（1976 a ）植物界に括けるケイ陵植 物の分布について（その1），䍹子菜網に打ける分布， 土肥誌，47，p. 296-300

高橋英一・三宅靖一(1976b) 植物界飞抢けるッイ酸植 物の分布について(その 3), 裸了植物, 羊爽植物, 鮮 苔植物に抢子る分布, 土肥誌, 47, p. 333-337

高橋英一・三宅靖一 (1981) 植物界飞括以る少人酸植物 の分布について(その5)，イネ科植物に物ける分有， 土肥誌，52，p. $503-510$

高橋英一・田中冣夫・三宅站一（1981）樗物界飞括以る 为イ酸植物の分布について(その6)，ッュクサ目一力

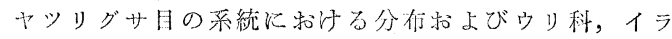
クサ科に和けるケイ酸集積，士肥誌，52，p. 511-515

TAkAtsukr, S. (1978) Precision of fecal analysis: a feeding experiment with penned sika deer. J. Mammal. Soc. Japan, 7, p. 167-180.

Takeoka, Y., K. Kondo, and P. B. Kaufman (1983) Leaf surface fine structures in rice plants culture under shaded, and non-shaded conditions. Japan, J. Grop Sci. ,52, p. 534--543.

Takeoka, Y., O. Matsumura, and P. B. Kaufman (1983) Studies on silicification of epidermal tissues of grasses as investigated by soft $\mathrm{X}$-ray image analysis. I. On the method to detect and calculate frequency of silica bodies in bulliform cell. Japan J. Crop Sci., 52, p. 544-550.

馆岡亚緒 (1956) スズメガヤ画科, キビ亚科の葉の解剖 学的特徵の再検討, 植物研究雑誌, 31, p. 210-218

Tomlinson, P. B. (1961) Anatomy of the Monocotyledons. II. Palmae, 453 p., Clarendon Press, Oxford

Tsuji, S., M. Minaki, and S. Osawa (1984) Paleobotany and paleoenvironment of the Late Pleistocene in the Sagami Region, central Japan. The Quaternary Research, 22, p. 279-296

TsukadA, M. (1967) Vegetation in subtropical Formosa during the Pleistocene glaciations and the Holocene. Palaeogeogr., Palaeoclimatol., Palaeoecol., 3, p. 49-64.

塚时松雄（1974）古生熊学 II. 応用論, 231 p., 共汒出 版，東宗

塚田松雄 (1980) 植物理酸体 (Phytolith), 軽石学雑誌, No. 6, p. 51-63

Turner, B. L. and P. D. Harrison (1981) Prehistoric raised field agriculture in the Maya lowlands. Science, 213, p. 399-405.
Twiss, P. G., R. M. Smith, and R. K. Krauss (1967) Composition of phytoliths from Andropogon scoparrius. Geol. Soc. Am. Abstr., p. 225.

Twiss, P. C., E. Suess, and R. M. Smith (1969) Morphological classification of grass phytoliths. Soil Sci. Soc. Amer. Proc., 33, p. 109-115.

TYrin, I. V. (1937) On the biological accumulation of silica in soils. Probl. Sor. Soil Sci., 4, p. 3-23 (USSR)

UMEмото, K.(1973) Mode of morphological forms of crystalline inorganic component in plants: Silicon bodies in wheat. Chem. Pharm. Bull. 21, p. 13911393.

Umemoto, K. and K. Hozumi (1973) Identification of the plant source of the Ghines crude drug "danzhu-ye" using the low temperature plasma ashing techniques. Microchimica. Acta (Wine), p. 301313.

梅村萠・近藤錬三（1984）野尻湖周辺の黑ボク土のソ゚ ラント・オパールについて，上肥要旨集，30，p. 149

Usov, N. I. (1943) Biological accumulation of silica in soils. Pochvovdenie, No. 9-10, p. 30-36 (USSR).

宇津川徽・細野 衛・杉原重夫 (1979) テフラ中の動物 理酸体 “Opal sponge spicules” そついて, ペドロジ スト, 23, p. $30-40$

Verma, S. D. and R. H. Rus'r (1969) Observations on opal phytoliths in a soil biosequence in southeastern Minnesota. Soil Sci. Soci. Amer. Proc. 33, p. $749-751$.

Watanabe, N. (1968) Spodographic evidences of rice from prehistic Japan. Jour. Fac. Sci. Univ. Tokyo, 3, p. $217-235$.

WAtanabe, N. (1970) A spodographic analysis of millet from prehistic Japan. Jour. Fac. Sci. Univ. Tokyo, 3, p. 357-379.

渡辺直経 (1973-4) 灰像による穀物遗残の検出法 (上, 下), 考古学研究, 20, p. 65-73, 21, p. 55-62

渡辺直経 (1981) 遺跡の灰から谼物をさぐる一灰像によ る鑑別, p. 201-219, 考古学のための化学 10 章（馬 淵久夫・富永 健編), 東京大学出版, 東京

Wilding, L. P. (1967) Radiocarbon dating of biogenetic opal. Science. 156, p. 66-67.

Wrlding, L. P. and L. R. Dress (1968) Biogenic opal in soils as index of vegetative history in Prairie Penisula. p. 96-103, In R. E. Bergstorm (ed.), The Quaternary of Illinois Unit. of Illinois Coll. Agric. Spec. Publ. No. 14, Urbana, Illinois.

Wilding, L. P. and L. R. Drees (1971) Biogenic opal in Ohio soils. Soil Sci. Soc. Amer. Proc., 35, p. $1004-1010$.

Wilding, L. P. and L. R. Drees (1973) Scanning electron microscopy of opaque opaline forms isolated from forest soils in Ohio. Soil Sci. Soc. Amer. Proc., 37, p. $647-650$. 
Wilding, L. P. and L. R. Drees (1974) Contributions of forest opal and associated crystalline phases to fine silt and clay fractions of soils. Clays Clay Miner., 22, p. 295-306.

Wilding, L. P. and L. R. Drees (1976) Biogenic opal in soils. Morphology, physical and chemical properties. p. 9-13, In H. HARWARD \& K. WADA (eds.), Amorphous and poorly crystalline clays. extended Anstract of U.S. -Japan Seminar, Oregon State Univ., Corvallis, Oregon.

Wilding, L. P. ,R. E. Brown, and H. Holowaychuk (1967) Accessibility and properties of occluded carbon in biogenetic opal. Soil Sci., 103, p. 56-62.

Wilding, L. P. ,C. T. Hallmark, and N. E. Smeck (1979) Dissolution and stability of biogenic opal. Soil Sci. Soci. Am. J. 43, p. 800-802.

Wilding, L. P., N. E. Smeck, and L. R. Drees (1977) Silica in soils: quartz, cristobalite, tridymide, and opal. p. 471-552, In J. B. Dixon and S. B. WEED (eds.), Minerals in soil environments,
Soil Sci. Sci. Amer., Madison, Wisconsin

Witty, J. E. and E. G. KNox (1964) Grass opal in some chestnut and forest soils in north central Oregon. Soil Sci. Soc. Amer. Proc., 28, p. 685-688. 山根一郎 (1973) 川渡山地草地に打ける土壤と植生, ○ ドロジスト，17，p.112-119

Yarilova, E. A. (1952) Grystrallization of phytolitharian in the soils. Dokl. Acad. Nauk. 83, p. $911-$ 912 (USSR).

YeGK, R. D. and F. GRAY (1969) Preliminary studies of opline phytoliths from selected Oklahoma soils. Pro. Okla. Acad. Sci., 48, p. 112-116.

YeCK, R. D. and F. Gray (1972) Phytolith size characteristics between Udolls and Ustolls. Soil Sci. Soc. Amer. Proc., 36, p. 639-641.

Yoshida, S., Y. Onishi, and K. Kitagishi (1962) Histochemistry of silicon in rice plant: III. Soil Sci. Plant Nutr. 8, p. 1-5.

吉田昌一 (1965) 水稲体中に括けるケイ素の存在㥞式と 生理的意義に関与る研究, 農研報告 B， 15， p. 1-59 
図版説明

写真図版 I.イネ科植物起源理酸体の走查型電子顕微鏡写真

A：エゾミヤコザサ (Sasa apoiensis)， B : シャコタンチク (Sasa kurilensis), G：アズマネザサ (Pleioblastus Chino), D：コマチダケ (Bambusa multiplex), E : ローズグラス (Chlolis gayana), F :オオニワホコリ (Eragrostis pilosa), G:オヒシバ (Eleusine indica), H: communis), I : イネ(Oriza sativa), J : メ シバ (Digitaria ciliaris), K : キビ (Panicum miliasceum), L : ヒエ (Echinaochloa utilis), M, O : トウモヒロコシ (Zea mays), N : コブナグサ (Arthraxon hispidus)，P：メガルカヤ (Themeda triandra subsp. japonica)，Q：オオアブラススキ (Spodiopogon sibiricus), R:オギ (Miscanthus sacchariflorus), S:チモシー (Phleum pratense), $\mathrm{T}:$ コギ (Triticum aestivum), U：オーチャード(Dactylis glomerata), V：ウシノケグサ (Festuca ovina), W : ホガエリガヤ (Brylkinia caudata).

写真図版 II. イネ科植物起源球酸体の走査型電子顕微鏡写真

A, L：トウモロコシ (Zea mays), B: ヨシ (Phragmites communis), C, W : イネ (Oryza sativa), D：ヒエ (Echinochloa utilis)， E， R：チマキザサ (Sasa palmata), F, X:アケボノザ サ (Pleioblastus Akebono), G : シバ (Zoysia japonica), H : オヒシバ (Eleusine indica), I : オー チャード(Dactylis glomerata), J : チヂミザサ (Oplismenus undulatifolius), K : ガルガヤ(Thmeda trianda subsp. japonica), M : ユムギ (Triticum aestivum), O：エゾミヤコザサ (Sasa apoiensis),

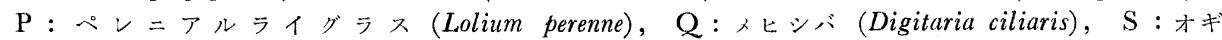
(Miscanthus sacchariflorus)， T:イタリアソライグラス (Lolium multiflozum) V: シロガネヨシ (Cortaderia selloana), N, T, U : 不明.

写真図版 III.イネ科植物特よび非イネ科草本類起源珪酸体の走查型電子顕微鏡写真

A：チヂミザサ (Oplismenus undulatifolius), B : トウモロコシ (Zea mays), C : 種名不明, D : ササ属 (Sasa spp.)，E，F，G：マュモ(Zizania latifolia)， H，J：不明（ブラジル，ラトソル 土から分離), I : 不明 (岩手県埋没黒ボク土から分離), $\mathrm{K}:$ 二ウボウムギ (Carex kobomugi), L : ワタスダ (Eriophorum vaginatum), M, O, P：エゾアブラガヤ (Scirpus wichurae), Q：スゲ属 (Carex spp.), R : ワラビ (Pteridium aquilinum), S : シダ類 (Peteropsida), T, U : ミズトクサ (Equisetum limosum), V, W : シンピジュウム属 (Cymbidium spp.)* *左. (表), 有（裏).

写真図版 $N$. 樹木起源珪酸体の走查型電子顕微鏡写真

$\mathrm{A}, \mathrm{J}$ : カシワ (Quercus dentata), B : ブナノキ(Fagus crenata), G：スダジイ (Castanopsis sieboldii), D：イヌビワ (Ficus erecta), E：キタコブシ (Magnolia kobus), F, G : タブ) (Persea thunbergii), I, K : アカガシ (Qercus acuta), H : ヤコウバシ (Lindera gluca), L : イスノ キ (Distylium racemosum), M : ケヤキ (Zelkova serrata), N : 南方材 (種名不明), O : エゾマッ (Picea jezoensis), P : クロマッ (Pinus thunbergii), Q : サシ (Palmae), R, S : クロッグ (Arenga tremula Becc. var. engleri)*， $\Gamma$ ：ヤエヤマヤシ (Satakentia liukiuensis)* 庄（裏)，右（表).

写真図版 V. 同一葉身 (Sasa apoiensis) から分離したタケ型理酸体の各種タイプ $1 〜 5$ はごく普通のタイプ，6〜9は稀なタイプ. 
近藤鍊三・佐瀬 隆 : 戝版 I

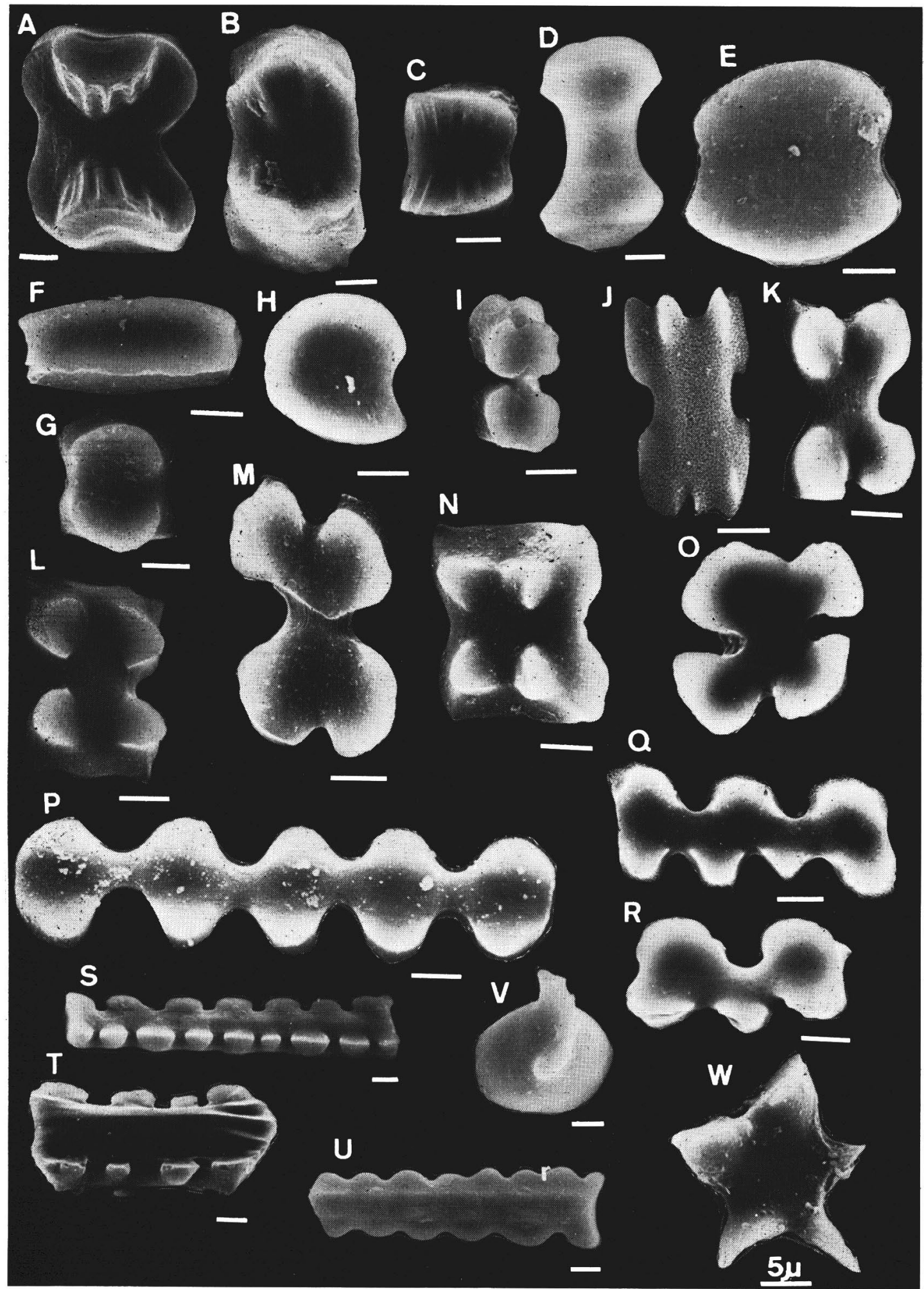


近藤鍊三・佐瀬 隆 : 困版 II

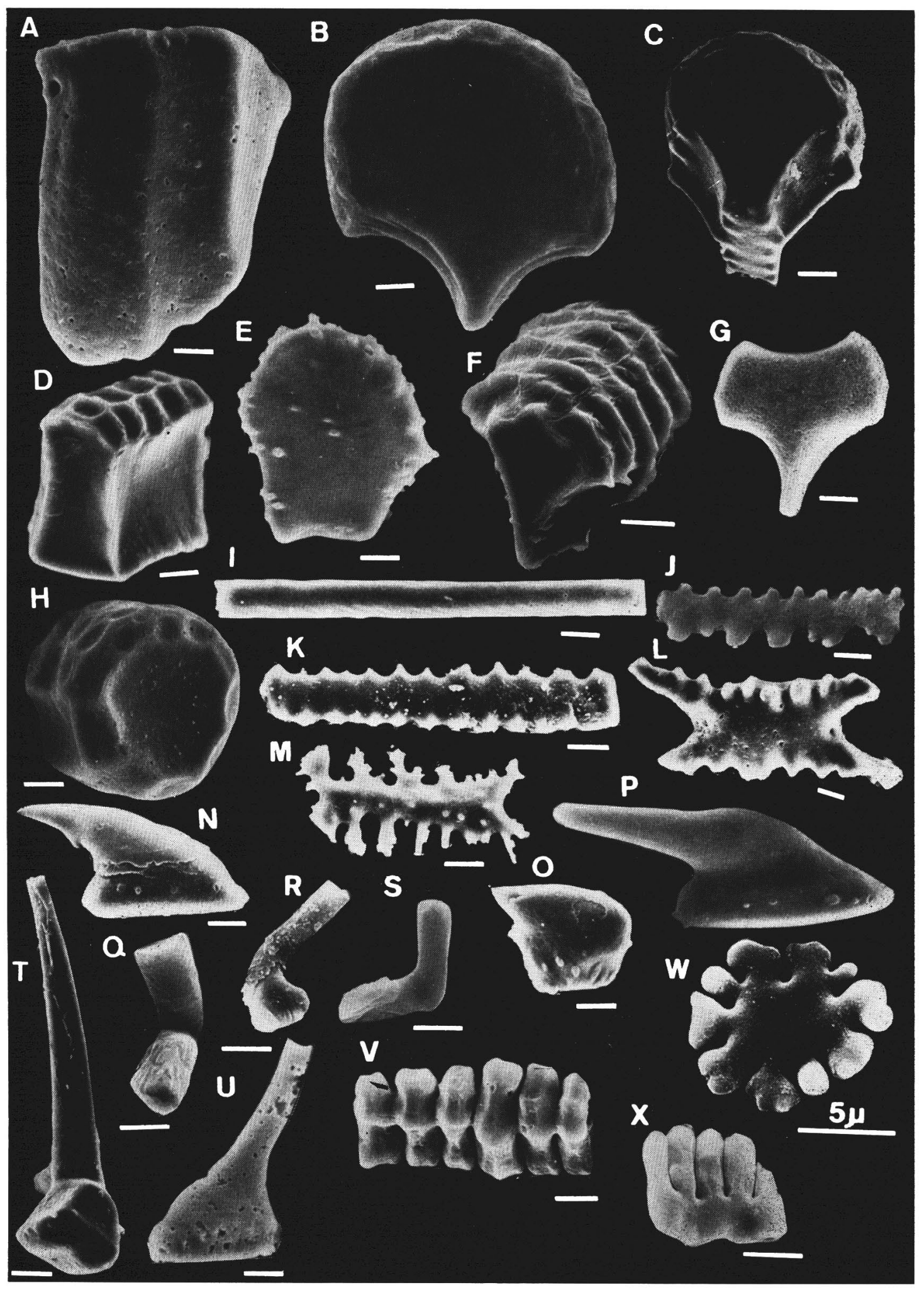




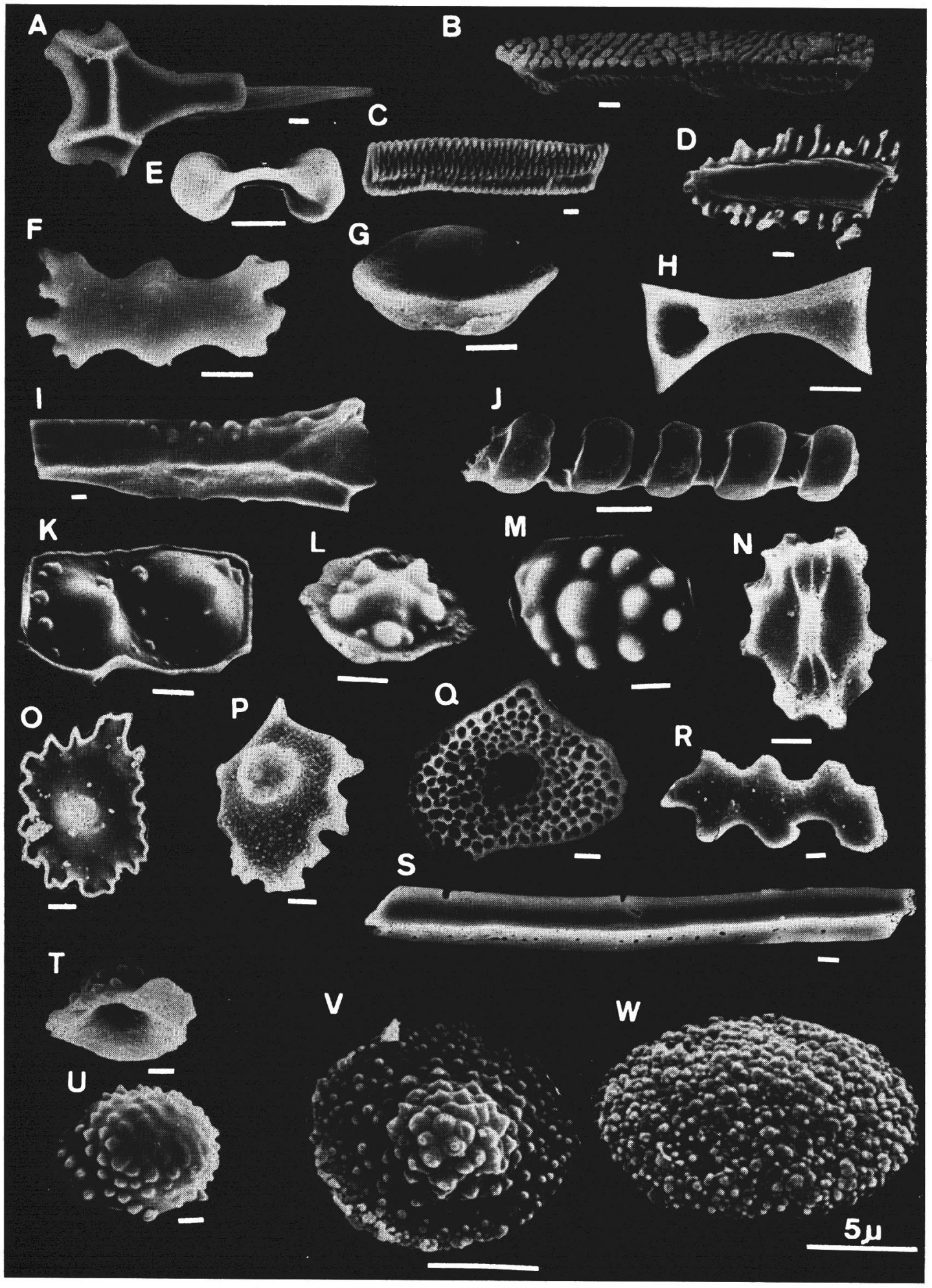




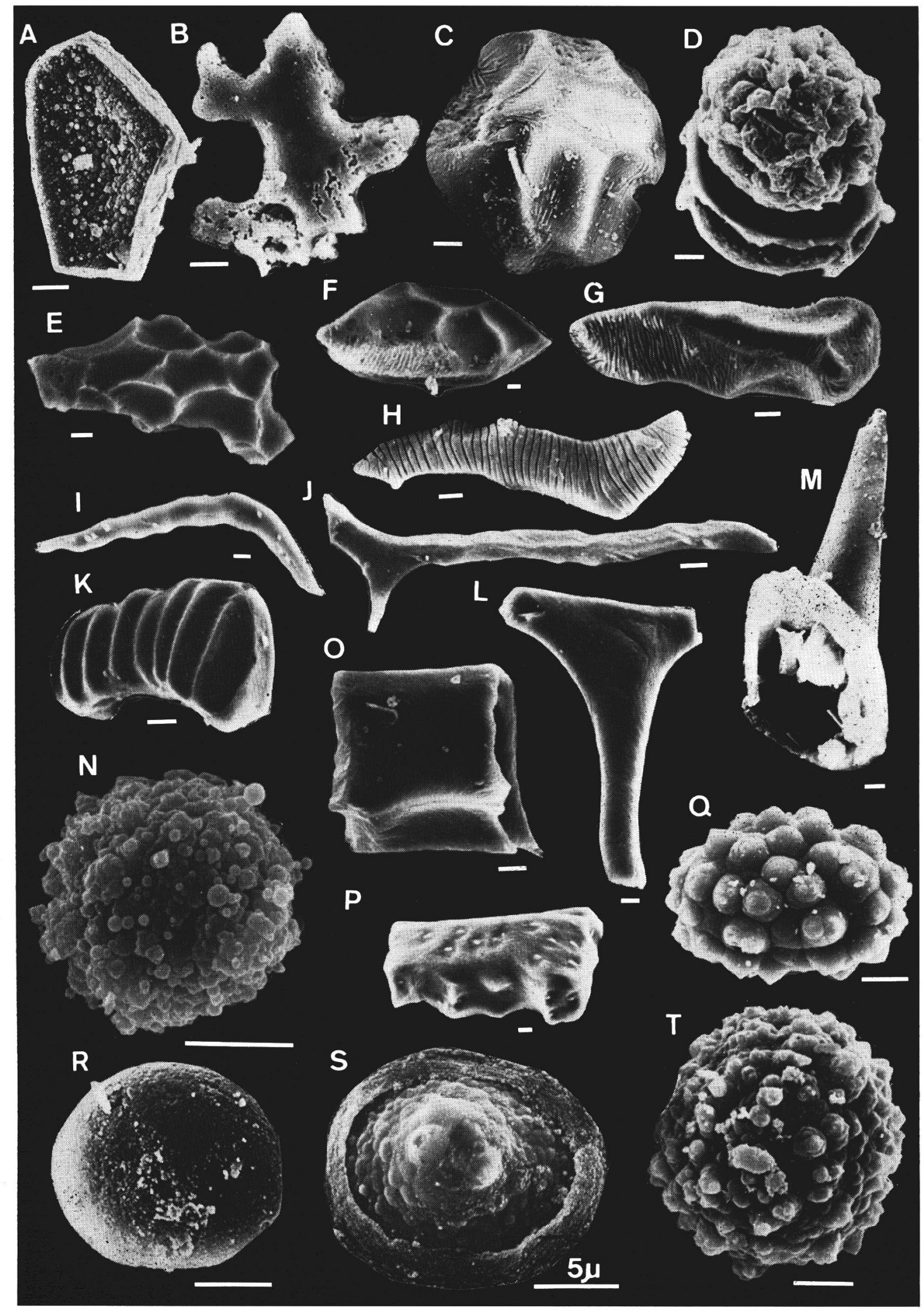


近藤錬三・佐瀬隆 : 図版 V
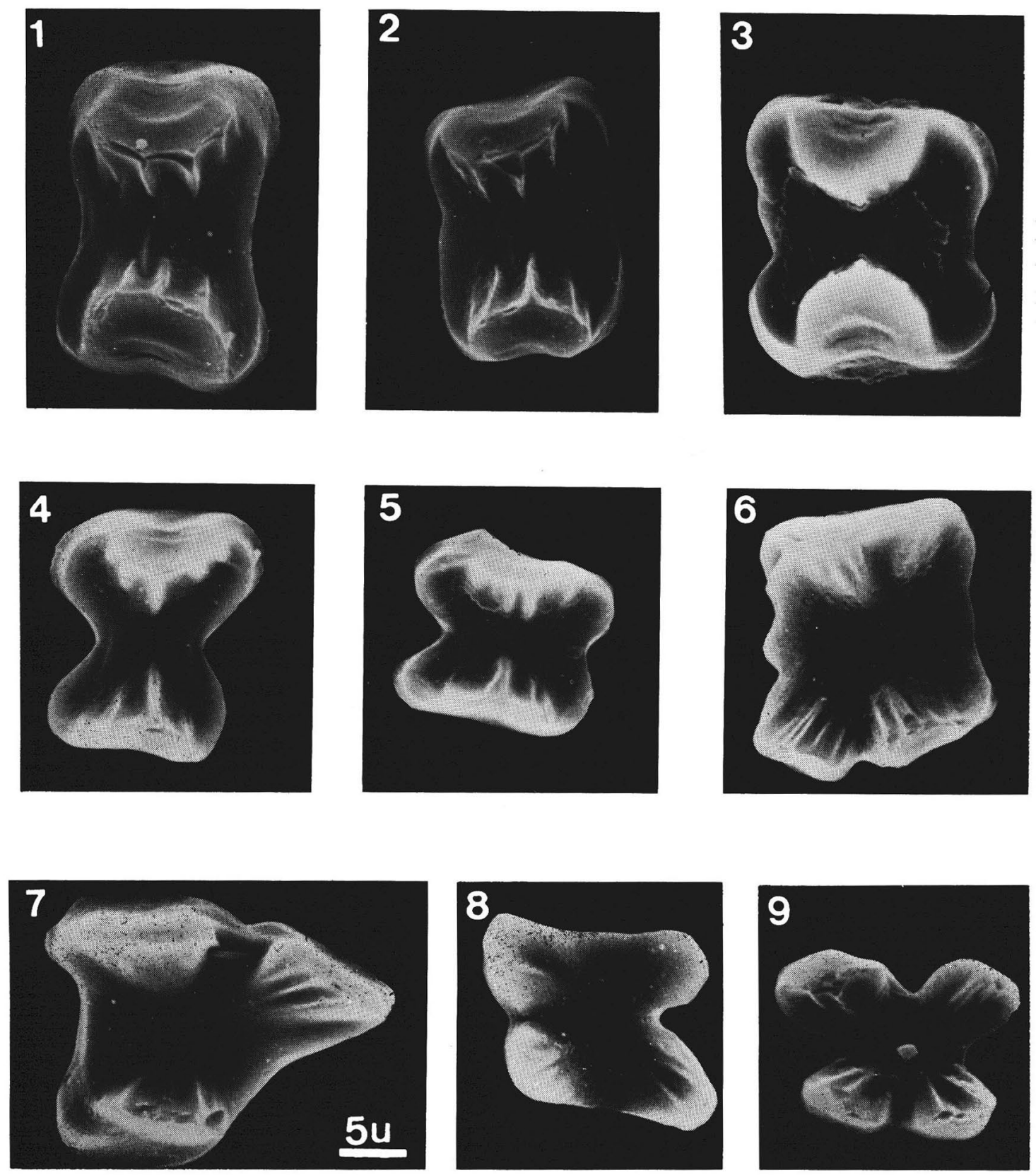